\title{
Macrostratigraphy of the Ediacaran System in North America
}

\author{
Daniel C. Segessenman \\ Shanan E. Peters \\ Department of Geoscience, University of Wisconsin-Madison, Madison, WI, 53706, USA \\ *Corresponding Author: segessenman@wisc.edu
}

\section{Preprint Note}

This manuscript has undergone peer-review and has been formally accepted for publication as part of a Geological

Society of America special publication entitled Laurentia: An Evolving Continent GSA Memoir. This

preprint was generated to facilitate the review process of another manuscript the authors have written that builds off the work presented here. Supplementary information, data, and figures will be available with the officially published version. Subsequent published versions of this manuscript may have slightly different content. Please feel free to contact either of the authors; we welcome feedback. Made with $\mathrm{LT}_{\mathrm{E}} \mathrm{X}$.

\begin{abstract}
Ediacaran sediments record the termination of Cryogenian 'Snowball Earth' glaciations, preserve the first occurrences of macroscopic metazoans, and contain one of the largest known negative $\delta^{13} \mathrm{C}$ excursions (the Shuram-Wonoka). The rock record for the transition between the Proterozoic and Phanerozoic in North America is also physically distinct, with much of the continent characterized by a wide variety of mostly crystalline Proterozoic and Archean rocks overlain by early Paleozoic shallow marine sediments. Here, we present quantitative macrostratigraphic summaries of rock quantity and type using a new comprehensive compilation of Ediacaran geological successions in North America. In keeping with previous results that have identified early Paleozoic burial of the 'Great Unconformity' as a major transition in the rock record, we find that the Ediacaran System has greatly reduced areal extent and volume in comparison to the Cambrian and most younger Phanerozoic systems. The closest quantitative analogue to the Ediacaran System in North America is the Permian-Triassic interval, deposited during the culminating assembly and early rifting phases of the supercontinent Pangea. The Shuram-Wonoka carbon isotope excursion occurs against the backdrop of the largest increase in carbonate and total rock volume observed in the Ediacaran. The putatively global Gaskiers glaciation ( $~ 580-579 \mathrm{Ma})$, by contrast, has little quantitative expression in these data. Although the importance of Ediacaran time is often framed in the context of glaciation, biological evolution, and geochemical perturbations, the quantitative expressions of rock area, volume, and lithology in the geologic record clearly demarks the late Ediacaran to early Cambrian as the most dramatic transition in at least the past $635 \mathrm{Myr}$. The extent to which the timing and nature of this transition is reflected globally remains to be determined, but we hypothesize that the large expansion in the extent and volume of sedimentation within the Ediacaran, particularly among carbonates, and again from the Ediacaran to the Cambrian, documented here over approximately 17\% of Earth's present-day continental area, provides important insights into the drivers of biogeochemical and biological evolution at the dawn of animal life.
\end{abstract}

\section{KEYWORDS}

Shuram-Wonoka, Gaskiers, Macrostratigraphy, Neoproterozoic, Geochronology, Carbon Isotopes 


\section{INTRODUCTION}

Over one hundred and fifty years ago, Alexander Murray used 'gas-escape' structures to correlate Neoproterozoic rock units for geological surveys across Newfoundland (Murray, 1869). Murray's 'gas-escape' structures are now recognized as Aspidella terranovica, some of the oldest known occurrences of macroscopic fossils possibly related to animals in the sedimentary record (Billings, 1872; King, 1980; Benus, 1988; Gehling et al., 2000; Menon et al., 2013). Organic interpretations of additional sedimentary features in Precambrian rocks were not widely accepted until a fifteen-year-old girl, Tina Negus, discovered frond-like fossils in the Charnwood Forest of England, later described and named Charnia by Trevor Ford (Ford, 1958). The realization that late Neoproterozoic rocks contained some of the oldest known animal-like macroscopic body fossils (Sprigg, 1947; Glaessner, 1959) eventually led to further biostratigraphic and geochronologic studies and the formal establishment of the Ediacaran Period (635-541 Ma), the first such addition to the International Geologic Time Scale in over a century (Knoll et al., 2006).

In addition to containing the oldest known fossils of macroscopic metazoans (Knoll and Carroll, 1999; Xiao and Laflamme, 2009; Droser and Gehling, 2015; Erwin, 2015; Bobrovskiy et al., 2018; Dunn et al., 2018), Ediacaran rocks document the termination of Cryogenian 'Snowball Earth' glaciation in the form of a basal cap carbonate (Hoffman et al., 1998; James et al., 2001; Kennedy et al., 2001; Kennedy and Christie-Blick, 2011; Ahm et al., 2019), protracted rifting of the supercontinent Rodinia and associated rift-drift transitions (Cawood et al., 2001; Cawood and Pisarevsky, 2017), the largest negative carbon isotope excursion measured in the rock record (Shuram-Wonoka excursion; Burns and Matter, 1993; Kaufman and Knoll, 1995; Grotzinger et al., 2011; Xiao and Narbonne, 2020), and possible evidence of multiple post-Cryogenian glacial episodes (Gaskiers and other unnamed events; Narbonne and Gehling, 2003; de Alvarenga et al., 2007; Chumakov, 2009; Hebert et al., 2010; Halverson and Shields-Zhou, 2011; Hoffman et al., 2012; Vernhet et al., 2012; McGee et al., 2013; Etemad-Saeed et al., 2016; Pu et al., 2016; Letsch et al., 2018; Linnemann et al., 2018; Yang et al., 2019; Chen et al., 2020). This is all followed by the appearance of almost all modern animal phyla during the Cambrian radiation (Knoll and Carroll, 1999; Valentine, 2002; Marshall, 2006; Erwin et al., 2011; Briggs, 2015).

Great strides have been made in understanding the Ediacaran and its critical transition with the Phanerozoic. Sequence stratigraphy has served as an important interpretive framework in this regard by environmentally contextualizing and facilitating the correlation of vari- ous proxy records (Sarg, 1988; Van Wagoner et al., 1988; Christie-Blick et al., 1995; Le Guerroué et al., 2006; Jiang et al., 2011; Macdonald et al., 2013; Smith et al., 2016a; Xiao et al., 2016; Shahkarami et al., 2020; Xiao and Narbonne, 2020). Although interpretations of proxies are always subject to revision and refinement, all of the substantive data used for understanding the Earth system are anchored by their physical positions within the rock record itself. The quantitative spatio-temporal distribution of rocks, their lithological compositions, and their relationships to other younger, older, and coeval rocks can also contain process signals that integrate the interactions between tectonics, climate, and biology. Thus, a quantitative understanding of the distribution and composition of rocks on continental and global scales over the duration of the entire Ediacaran has the potential to complement our understanding of Earth systems evolution by better contextualizing our sampling of Earth history and by providing additional data with which to detect and test for process signals that are often difficult to discern at the field scale.

For example, the "Wilson cycle" of ocean basin opening and closure (Wilson, 1966), and associated supercontinent break-up and assembly, has left an unambiguous and overwhelmingly strong signal in the continental-scale, $1^{\text {st }}$ order $\left(\sim 10^{8}\right.$-year $)$ distribution and extent of Phanerozoic sedimentary rock globally and in North America (Dewey and Spall, 1975; Vail et al., 1977; Ronov et al., 1980; Nance et al., 1988; Condie 1998, 2000, 2004; Groves et al., 2005; Miller et al., 2005; Peters 2006; Hawkesworth and Kemp, 2006; Cawood et al., 2013; Nance et al., 2014; Peters and Husson, 2017; Wu et al., 2017; Merdith et al., 2019). Superimposed on this $1^{\text {st }}$-order Phanerozoic supercontinent cycle are $2^{n d}$-order $\left(\sim 10^{7}\right.$-year-year $)$, continental-scale sequences, first identified by Larry Sloss in North America as "tectonostratigraphic" units (Sloss, 1963), which formed in response to the accretion of arcs and other marginal tectonic events (Walcott, 1972; Dott, 1983; Haq et al., 1987; Ross and Ross, 1987; Gurnis, 1992; Burgess and Gurnis, 1995; Burgess et al., 1997; Miller et al., 2005; Burgess, 2008; Haq and Schutter, 2008). Although the $1^{\text {st }}$ order Wilson cycle is not readily apparent at the field-scale, $2^{n d}$ order unconformities defining Sloss Sequences are readily identified in the field. One of Sloss's key insights was that these unconformities bound "genetically related" bodies of rock, establishing a conceptual foundation for sequence stratigraphy (Sloss, 1988; Christie-Blick and Driscoll, 1995; Catuneanu et al., 2011, Dott, 2014). Superimposed on Sloss sequences are $3^{r d}$-order, $\sim 1$ Myr sequences, in some cases formed during relatively short-lived, global drops in baselevel, like that which occurred during late Ordovician glaciation, 
and others reflecting more local, basin-scale controls on subsidence and sediment supply. And so it continues, on to $4^{t h}$ and $5^{t h}$ order sequences, which are superimposed on all lower-order sequences that form in response to a different set of shorter-duration shifts in the balance between accommodation and sediment supply, reflecting a mixture of global and regional processes (Miall, 2016).

Macrostratigraphy (Peters 2005, 2006, 2008; Peters and Heim, 2011b; Husson and Peters, 2017; Peters et al., 2018; Peters and Husson, 2018; Peters et al., 2021) was developed as an analytical framework with which to quantitatively measure the entire range of variability in the rock record, including that which is qualitatively expressed by sequence stratigraphic architecture. Decades of work have enabled the construction of a descriptive and correlation framework for Ediacaran successions in North America (Narbonne et al., 2012; Xiao and Narbonne, 2020) and here we build on this by integrating published descriptions of Ediacaran successions into a comprehensive, macrostratigraphic dataset capable of quantifying many different regional- and continental-scale properties of the known Ediacaran rock record. Our primary goal herein is to frame Ediacaran Earth systems within the variability of the rock record itself. This objective is particularly important in the case of the Ediacaran because this system in North America is restricted to the modern-day continental margins, whereas the overlying Cambrian System covers much of the continent. Thus, the relationship between Ediacaran glaciations, carbon isotope excursions, and biological evolution leading into the Cambrian explosion should be interpreted within the broader context of a geologic record that changes dramatically from the Neoproterozoic to Paleozoic.

\section{METHODS}

Our general methodology follows that of macrostratigraphy (Peters, 2006; Peters et al., 2018), which uses as its fundamental currency the duration and properties of rock units that are lithologically- and/or geochronologicallydistinct at a given location and at a given scale of resolution. Multiple physically and chronologically juxtaposed rock units comprise columns. In the case of sedimentary rocks, a column might consist of multiple conformable units defined by different lithologies that are vertically juxtaposed, thereby establishing relative chronological control. This group of contiguous and continuous sediments might then be distinguished from another such group of sediments by a "gap", establishing two "gapbounded" successions. In the case where all sedimentary rocks are included, macrostratigraphy provides a quantitative summarization of sequence stratigraphic archi- tecture. However, macrostratigraphy is more flexible in defining what constitutes a gap than sequence stratigraphy, meaning it can be applied to subsets of lithologies within sequences (e.g., carbonates only, with all other rock types treated as "gaps"; Peters, 2008) and to igneous rocks (Peters et al., 2021). Macrostratigraphic quantities, like total rock area and volume, are derived by aggregating the data for the target lithology (e.g., shales, all sediments, or plutonic rocks) and analyzing them over all columns in the focal area.

In this study, columns were specifically constructed to capture the entire Ediacaran System of North America, along with the rocks immediately bounding the Ediacaran geochronologically. These columns were compiled from rock unit descriptions and regional syntheses in journal and survey publications as well as from geologic maps. The distinction between rock units was generally made at the greatest level of detail available, but operationally the effective resolution was "lithostratigraphic" units (e.g. some locations subdivided units into relatively thin member-level designations whereas in other areas units are extensive undifferentiated group-level units). Interformational gaps (unconformities between two distinctly separate rock units) were included when identified and reported in the literature. Intraformational gaps (unconformities identified within a single rock unit) were only included if there was a distinct lithologic or environmental change between the bounding units. Less than $10 \%$ of units, primarily in regions with structural complexity or limited exposure and borehole data, have no clear published thickness estimate. In cases where thickness was unknown, the thicknesses of rock units of similar age in the surrounding areas were used to generate a median thickness estimate. The resulting compilation of units in each column has an effective temporal resolution sufficient to resolve most $2^{n d}$ and $3^{r d}$ order-scale changes in temporal continuity.

The boundaries of the geographic area for each column were estimated by using the combined known surface/subsurface extent of its constituent geologic units. If there was a substantive lateral change in the properties of at least one geologic unit, then a new column was generated. Substantive changes initiating the definition of a new column included significant lateral facies transitions, the disappearance or "pinching out" of major units, and the appearance of distinct geologic units. The principle of lateral continuity was applied to provide complete coverage between control areas. This assumption was made conservatively, particularly in areas with greater structural complexity. For example, columns from the East coast of NA have areas that broadly conform to regional patterns of deformation, not a palinspastic re- 
construction. Polygon areas were drawn manually using the free, open-source utility geojson.io in preparation for entry into the GIS component of the Macrostrat database. Columns were grouped into paleotectonic terranes, with further subdivisions of the large Laurentian block (Fig. 1).

The terranes ('West Avalonia', Ganderia, and Carolinia) are interpreted to be volcanic arcs and microcontinents rifted from the margin of Gondwana, all of which were accreted to Laurentia's margin during the early to mid-Paleozoic (Schofield et al., 2016; Murphy et al., 2019). Columns located in regions associated with the Neoproterozoic paleocontinents of Baltica (North-central to NW Alaska; Fig. 1) and Amazonia (southern Central America) are also included in this dataset, though they were only included in the aggregate Ediacaran analyses. We refer to western, southeastern, and northeastern Laurentia as 'realms' within the same continental block. The NE Alaska columns located in the North Slope subterrane and NW Canada (Peri-Laurentia) were included in the aggregate Ediacaran results but were not included in the individual paleotectonic terrane/realm results due to contention over their association with W Laurentia or NE Laurentia strata (Fig. 1; Gibson et al., 2021). The terrane and realm groupings used here reflect usage in the literature, though the tectonic affinity of NE Laurentia (Nunavut, Greenland, and Svalbard) also remains ambiguous (Faehnrich et al., 2019).

All 201 columns compiled for this study are shown in Figure 1 in comparison to the geographic footprint of the 212 columns that contain Ediacaran rocks in the lowerresolution Macrostrat database project for the entire rock record of North America (e.g., Peters and Gaines, 2012; Husson and Peters, 2017; Peters and Husson, 2017). The complete dataset for the Ediacaran System of North America, compiled as described above, consists of 1,357 rock units from 201 columns (Fig. 1). A complete list of the references used in this study is provided in a supplement and linked to data records in Macrostrat (S1: Extended References).

After compiling basic physical properties for all units and columns, additional attributes, including geochronological and stable isotopic measurements, fossil occurrences (microscopic and macroscopic), sedimentary structures (including concretions and other distinctive features), and paleoenvironmental interpretations were compiled and linked to the entered rock units. Published correlations for each geologic unit were also recorded, when available, and used in the refinement of age models within and between columns (see below).

All data were entered into the Macrostrat database (macrostrat.org) with a distinct project designation, mak- ing it possible to leverage the existing infrastructure for data management and dissemination (Peters et al., 2018). This system also generates an initial continuous-time age model using the constraints provided by basic superposition and correlations to chronostratigraphic time bins that are either part of, or that can be correlated to, the current International Commission on Stratigraphy timescale (ICS; Cohen et al., 2013; updated, Chart v 2020/03). Changes to any of the ICS boundary ages, such as a proposed revised age of $\sim 539 \mathrm{Ma}$ for the EdiacaranCambrian boundary (Linnemann et al., 2019; Hodgin et al., 2021), automatically propagate to the relative age model for columns and to all data linked to those rock units. A more complete description of Macrostrat's architecture, features, accessibility, and initial age model construction steps can be found in Peters et al. (2018).

Once all pertinent data were compiled and entered into Macrostrat, the initial naïve age model was modified using published regional correlations and geochronologic measurements. A total of 146 radioisotopic dates (Fig. 2; Table 1; supplementary Fig. S2) were linked to Ediacaran units (a complete set of radioisotopic dates and references utilized for this purpose are in the supplement S2: Radioisotopic Dates). Published regional correlations were used conservatively when modifying the initial age model. For example, a correlation based solely on lithologic similarity, such as the oolite marker beds in the Johnnie Formation of Death Valley and a similar oolite horizon in the Clemente Formation of Mexico, were not forced into time equivalence, but they may still emerge as such. We also avoided forcing time equivalence of rock units containing Ediacaran macrofossils due to their enigmatic relationships. Global correlations of Ediacaran assemblages are typically based on their interpreted affinity with Avalon, White Sea, or Nama groupings, which have questionable utility for biostratigraphy (Gehling and Droser, 2013). In this manner, we constructed an age model for the Ediacaran of North America that incorporates the basic law of superposition, with constraints on time provided by correlations to calibrated chronostratigraphic time bins, stratigraphically positioned geochronologic measurements, and correlations between key strata with time significance. The purpose of the age model used here is to provide an up-to-date working hypothesis for the correlation of all Ediacaran successions in a continuous-time representation that makes as few assumptions as possible. Like all models, our age model contains inaccuracies and is subject to ongoing revision as new data and new constraints are acquired.

It is important to note that we do not assert that the dataset compiled for this study is free of inaccuracies of multiple different kinds at the level of individual 


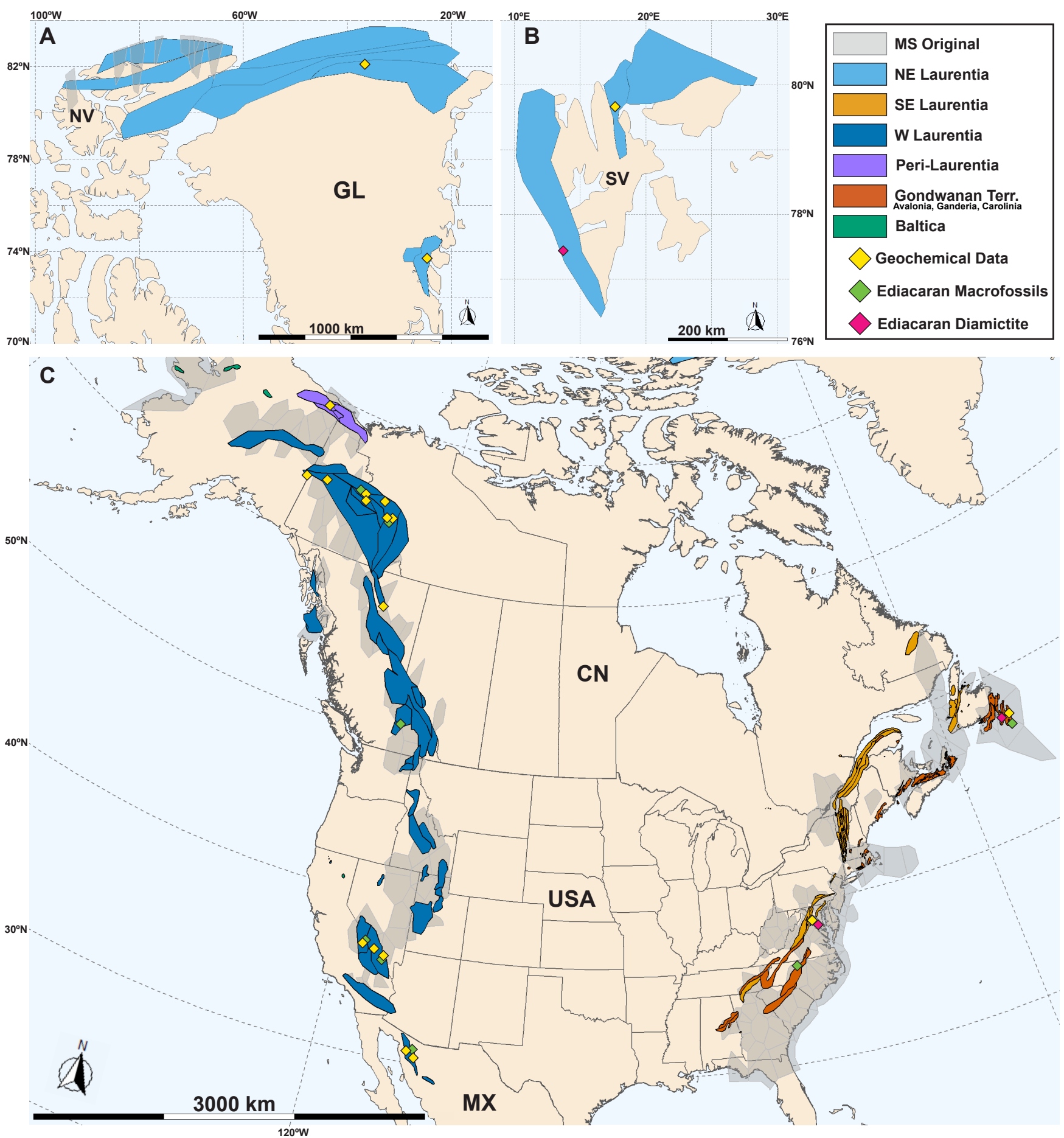

Figure 1: Mapped polygons representing areal extent of the Ediacaran System of North America from both the mesostrat dataset constructed for this study (colored polygons) and for coarse level Ediacaran data already in the Macrostrat database (gray transparent polygons). Polygons have been colored based on their association with various tectonic terranes and realms. Diamond shaped points are approximate locations of carbon isotope analyses (geochemical data), fossil occurrences, and Ediacaran rocks interpreted as glacial diamictites compiled for this study. A) Map of Nunavut, Canada (NV) and Greenland (GL), B) Map of Svalbard (SV), and C) Map of continental North America, including Canada (CN), the United States of America (USA), and northern Mexico (MX). 


\begin{tabular}{cccccc}
\hline Terrane $/$ Realm & No. Units & No. Cols & No. Dates & Area $\left.\mathbf{( k m}^{\mathbf{2}}\right)$ & Vol. $\left(\mathbf{k m}^{\mathbf{3}}\right)$ \\
\hline Amazonia & 4 & 2 & 4 & 22,300 & 111,500 \\
Avalonia & 211 & 40 & 51 & 39,800 & 356,800 \\
Baltica & 6 & 4 & 1 & 7,000 & 1,000 \\
Ganderia & 126 & 25 & 39 & 13,000 & 62,600 \\
Carolinia & 53 & 8 & 10 & 60,000 & 9333,200 \\
SE Laurentia & 309 & 61 & 18 & 115,500 & 275,600 \\
W Laurentia & 506 & 45 & 21 & 766,400 & $1,443,100$ \\
NE Laurentia & 120 & 12 & 2 & 336,800 & 308,200 \\
Peri-Laurentia & 22 & 4 & 0 & 48,700 & 51,000 \\
Total & 1,357 & 201 & 146 & $1,409,500$ & $3,543,000$ \\
\hline
\end{tabular}

Table 1: Number of units, columns, radioisotopic dates, estimated total area, and estimated total volume (volume does not include non-Ediacaran portions of columns) calculated for all Ediacaran aged rocks in each tectonic terrane/realm, and for the North American total.

rock units, sequences, and columns. However, our goal herein is not to use this compilation to make definitive statements about the age of any specific unit, event, or measurement that has been linked to Ediacaran rocks and time. Instead, we analyzed the entire Ediacaran System of North America quantitatively in order to generate summary statistics that characterize the system, as a whole, in a self-consistent fashion and as we understand it today. This statistical, aggregate approach means that it is possible for the majority of our individual unit data points to be incorrect in detail but for the underlying aggregate patterns to still be accurate reflections of what would have been measured if each individual unit were perfectly resolved, so long as errors are randomly distributed among units (see Adrain et al. (2000) for an excellent example of this phenomenon in a macroevolutionary analysis of trilobite diversity). This does not, however, mean that all of the quantities we derive are straightforward to interpret. For example, many of our columns are located in regions that have been structurally deformed. This makes some derivative aggregate quantities, like area and volume, more complicated in their interpretation. However, even in regions that have been deformed, sedimentary successions have some thickness and the areas of our columns do incorporate many structural boundaries of note. Our aggregate statistics do, we believe, well characterize the aggregate properties of the Ediacaran in North America as it exists today and provide a basis for reconstruction (see also the description below of scaling for comparison to the comprehensive lower resolution North American dataset).

All published carbonate stable carbon $\left(\delta^{13} \mathrm{C}\right)$ and oxygen $\left(\delta^{18} \mathrm{O}\right)$ isotope measurements from North American Ediacaran-aged sediments were also compiled, with geographic location of the samples linking them to the compiled units and positions of samples relative to compiled stratigraphic boundaries linking them to relative positions within units. Using these positions, each measurement can be assigned an individually precise age (and, in aggregate, accurate age in the case of randomly distributed errors) from the age model using linear interpolation between lithological boundaries serving as anchors. It is important to note that carbon isotope values, often interpreted as part of the Shuram-Wonoka excursion, were not explicitly used in the construction of the age model. However, published age interpretations are typically influenced by chemostratigraphic correlation when it is available, so it is likely that there is an indirect effect of this excursion on published correlations and, therefore, the age model used here. Compiled carbonate stable carbon $\left(\delta^{13} \mathrm{C}\right)$ and oxygen $\left(\delta^{18} \mathrm{O}\right)$ isotope measurements from North America Ediacaran sediments are included in the supplementary information and are available through the measurements route of Macrostrat's API (S3: Carbonate Geochemistry).

Having captured lithology, thickness, and other basic descriptive attributes of the Ediacaran rock record using the Macrostrat GIS and temporal age model system, we then computed aggregate metrics describing rock quantity as a volume flux (derived by summing over the product of thickness and column area, divided by the duration of each unit intersecting each time increment). Single units assigned multiple lithologies were assigned volumes based on the approximate proportionality of lithologies within them. In most of the results presented here, lithologies are grouped into four main classes: 1) intrusive igneous rocks, 2) volcanic/volcaniclastic rocks, 3) siliciclastic rocks, and 4) carbonates. Each of these classes were further subdivided into more specific lithologies (e.g., dolomite, limestone, shale, basalt). To allow more direct comparison of our new, higher-resolution Ediacaran compilation to the existing Macrostrat compilation in the Phanerozoic, column areas of the dataset compiled for this study were scaled by the mean of the 
percent difference for each Myr timestep between the two Ediacaran datasets (factor of 1.85; see supplementary Fig. S1).

\section{RESULTS}

\section{Results Overview}

Of the 1,357 rock units compiled herein, 539 are of an Ediacaran age and the remaining 818 represent the succession of overlying or underlying non-Ediacaran units. Of the 539 Ediacaran units, 428 contain sediment/metasedimentary rocks, 99 contain volcanic/volcaniclastic rocks, 160 contain intrusive igneous rocks, and 50 contain crystalline metamorphic rocks (note that one unit can have multiple lithologies). The total area covered by the 201 Ediacaranbearing columns compiled here is $1,409,500 \mathrm{~km}^{2}$. Of these, 141 columns covering $\sim 1,393,000 \mathrm{~km}^{2}$ contain sedimentary or metasedimentary rock units, which have a total combined Ediacaran-aged volume of approximately $2,789,000 \mathrm{~km}^{3}$. This represents a complete accounting of all Ediacaran (94 Myr in duration) rocks over $\sim 17 \%$ of Earth's continental crust (North America; Fig. 1, Table 1). By comparison, sedimentary deposits in the shorterduration (55.6 Myr) Cambrian System in the original Macrostrat compilation in NA cover almost eight times more area at $\sim 10,809,000 \mathrm{~km}^{2}$ and have almost four times more volume at over $9,550,000 \mathrm{~km}^{3}$, representing a total net rate of Cambrian sediment accumulation that is over three times that of the Ediacaran, even after adjusting the Ediacaran estimates herein upward to minimize differences with the original Macrostrat NA data.

Below we first summarize results from within each of the paleotectonic blocks sampled here. Together, these regional records combine to make the aggregate quantitative summary of the Ediacaran System of North America, with which we conclude.

\section{Avalonia}

Avalonia comprises parts of Great Britain (not included in this study), southeastern Canada, and northeastern New England, USA (supplementary Fig. 1D of this study for West Avalonia; Fig. 2 of Schofield et al., 2016 for Great Britain's East Avalonia). Avalonia is thought to have been located on the active subducting margin of Gondwana that underwent a transition from subduction to rifting (see figures in Murphy et al., 2019 for various reconstructions). Indeed, this terrane served as one of the foundations in the development of the Wilson cycle model (Wilson, 1966; Murphy et al., 2019; Wilson et al., 2019).
Over the past half-century, four distinct tectonic phases have been identified in Avalonia: 1) pre-main phase magmatism ( 760-650 Ma), 2) main phase arc magmatism ( 640-570 Ma), 3) arc to platform transition ( $\sim 600-540 \mathrm{Ma})$, and 4) platformal (continental) succession from latest Ediacaran through to the Early Ordovician (Murphy et al., 2019). A comparatively high area of plutonic units throughout the early Ediacaran, pulses of increased rock volume with high proportions of volcanics from 635-570 Ma, and an increasing proportion of siliciclastics reflect an arc to platform transition after $\sim 580 \mathrm{Ma}$, consistent with current interpretations of Avalonia's latest Neoproterozoic tectonostratigraphic history (Fig. 3A; Murphy et al., 2019; van Staal et al., 2020). These quantities reflect the signatures of the transition of the subcontinent from subduction arc magmatism to rift magmatism as it and other terranes (i.e., Carolinia, Ganderia, Meguma) were rifted from Gondwana, with a period of transtensional displacement. Full separation of Avalonia from Gondwana did not occur until as late as $~ 490$ Ma (Bevier et al., 1993; Mancuso et al., 1996; O'Brien et al., 1996; Pe-Piper et al., 1996; Murphy et al., 1997; Currie and McNicoll, 1999; Hatcher, 2010; Franke et al., 2017). The Avalonian terrane was accreted to Laurentia during the Early Ordovician to Early Devonian Appalachian-Caledonide orogeny (Domeier, 2016; Waldron et al., 2019; van Staal et al., 2020). The terrane and entire marine platform of the Laurentian margin, including Avalonia, was subsequently deformed during the Pangea-forming Late Carboniferous Variscan orogeny (Winchester et al., 2002; Smit et al., 2018), and again by the breakup of Pangea and the opening of the Atlantic basin, which resulted in the separation of the terrane into East and West subterranes.

Carbonates are not a significant component of sediments in Avalonia, likely due to the large supply of clastic sediment available to fill available accommodation. This has made it difficult to place the Shuram-Wonoka excursion within Avalonia's well constrained geochronology (Myrow and Kaufman, 1999), though measurements of carbonate material in siliciclastics have been used to identify and constrain its occurrence (Canfield et al., 2020). The Gaskiers Formation (Newfoundland, CA), which is the primary evidence of the Gaskiers glaciation between 580-579 Ma (Pu et al., 2016), is found within the Avalonia terrane. However, the Gaskiers glaciation does not appear to be associated with any pronounced expression in rock quantity or type (Fig. 3A), perhaps because Avalonia was a very active portion of Gondwana during the Ediacaran in comparison to its more proximal counterparts in Ganderia and Carolinia. The development of Avalonian platformal successions occurred from 


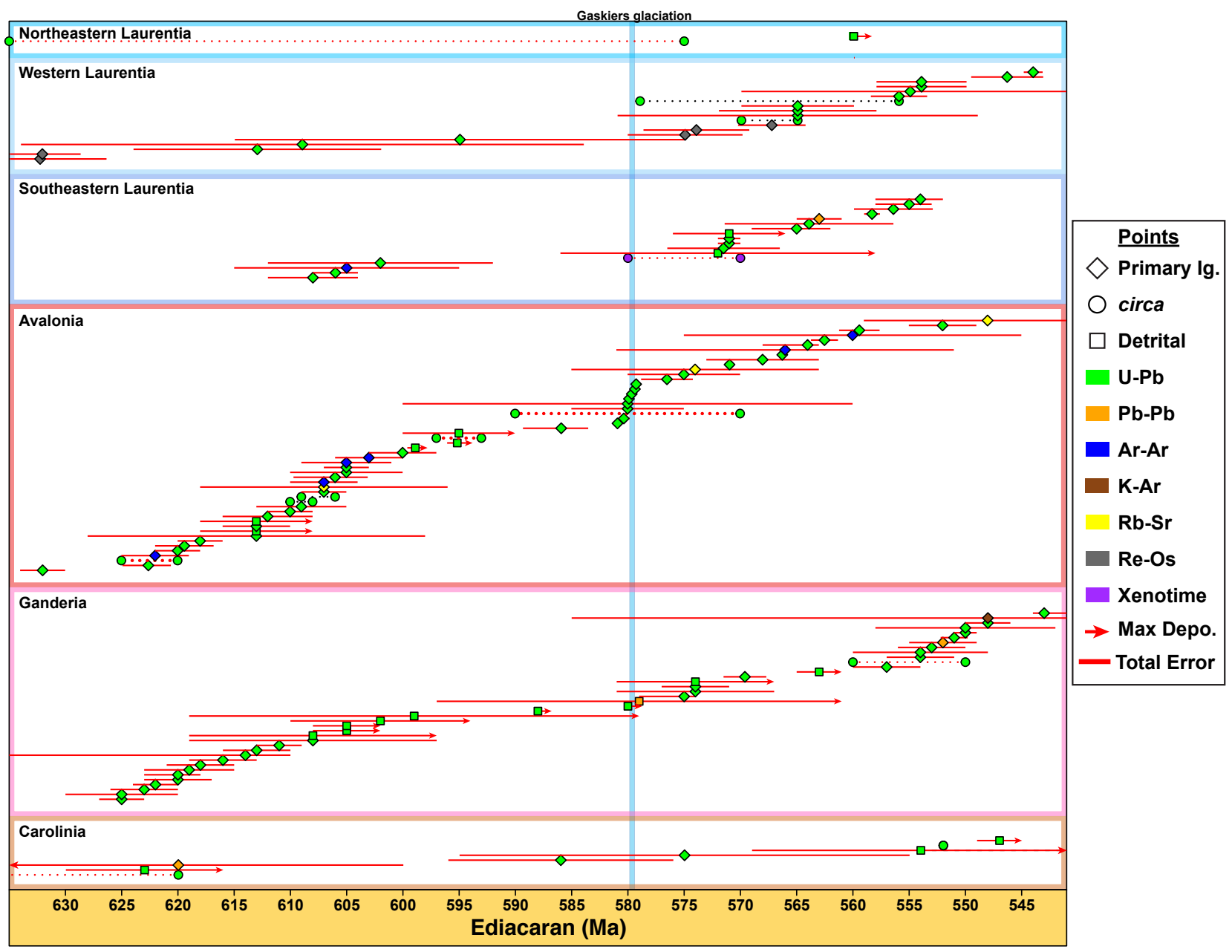

Figure 2: 'Caltech-style' plot of radioisotopic dates used to construct the Ediacaran mesostrat age model (colored by radioisotopic system) and their measurement error. A $0.1 \%$ additional tracer uncertainty has been added to dates from the U-Pb system for comparison with other systems. Diamond shaped points represent primary igneous measurements, square shaped points represent max depositional ages from detrital zircons, and circle-shaped points with dotted lines between them represent age ranges reported as 'circa'. A complete reference list of radioisotopic dates for the mesostrat database can be found in Supplement S2: Radioisotopic dates. A map showing the locations of radioisotopic dates relative to the terranes/realms they belong to can be found in Supplemental Figure S1. 
the late Ediacaran to the Early Ordovician in extensional and transtensional basins, in which the distinctive Avalonian fossil assemblages, such as the Mistaken Point fauna (Newfoundland) or the Charnwood Forest fauna (Great Britain), have been documented (Landing, 1996; O'Brien et al., 1996; Liu et al., 2015; Murphy et al., 2019). The occurrences of Avalonian fossil assemblages coincide with the arc to platform transition, which is marked by a decrease in the volume of volcanics and a subsequent rise in siliciclastics (Fig. 3A). Overall, macrostratigraphic patterns in Avalonia, and the Gondwanan terranes preserved in North America, reflect primarily proximal tectonic events, with little or no superimposed global signal (Fig. 3A,D).

\section{Ganderia and Carolinia}

Ganderia and Carolinia have similar Ediacaran tectonic histories, though they are distinct tectonostratigraphic terranes. Ganderia currently encompasses strata exposed in Great Britain (not included in this study), southeastern Canada, and New England, USA. Carolinia is currently located in the southeastern USA (Supplementary Fig. 1; van Staal et al., 2012). Both Ganderia and Carolinia were in close proximity as a part of the Gondwanan margin during the Ediacaran, were rifted from Gondwana in the early Paleozoic, and were accreted to the Laurentian margin during the Taconic orogeny and the closing of the Iapetus seaway (Murphy et al., 2004; van Staal et al., 2012). Avalonia, Carolinia, and Ganderia were all deformed and metamorphosed by orogenic events associated with the construction of Pangea, though Carolinia and Ganderia were located on the Taconic orogen collision front with Laurentia. Similar to Avalonia, Ganderia was separated into an east and west component by Pangea rifting and the formation of the Atlantic Ocean, whereas Carolinia has only been identified in the southeastern USA (van Staal et al., 2012).

Ganderia and Carolinia have similar macrostratigraphic patterns, though they differ in overall lithologic expression. Ganderia exhibits little preserved rock volume with a volcanically dominated pulse from $\sim 560-550$ Ma (Fig. 3B). Similarly, Carolinia has little preserved rock volume besides a siliciclastic pulse from $\sim 557-541$ Ma (Fig. 3C). Ganderia's rock volume flux is dominated by volcanics and coincides with an increase in plutonic unit area during the latter half of the Ediacaran. Ganderia's dominantly igneous Ediacaran record lacks significant sediment volume, due either to unroofing or, perhaps more likely, to an original lack of accommodation. By contrast, Carolinia's dominantly siliciclastic pulse of preserved rock volume ( 557 Ma) suggests that accom modation within the terrane was created by renewed
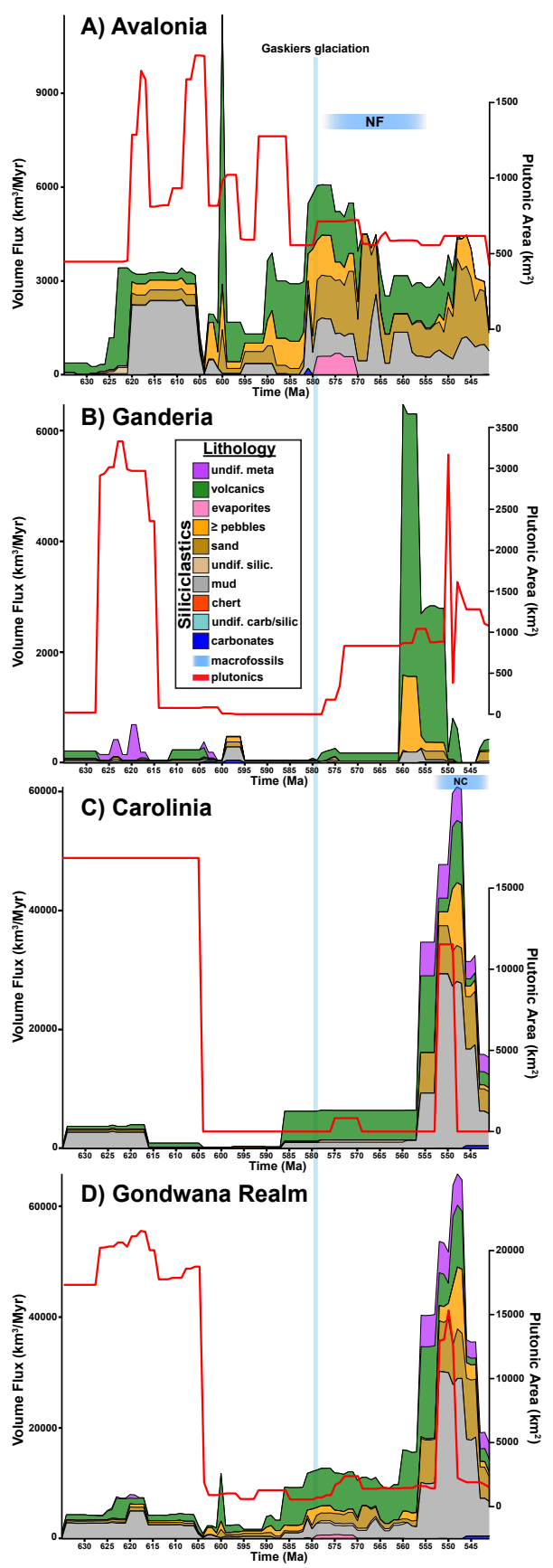

Figure 3: Individual plots of calculated volume flux $\left(\mathrm{km}^{3} / \mathrm{Myr}\right)$ divided by gross lithologic characteristics and calculated areas of Ediacaran age plutonics for each Gondwanan tectonic terrane from the mesostrat dataset. The Gaskiers glacial interval and Ediacaran macrofossil occurrences have been highlighted for each terrane. A) Avalonia; NF = Newfoundland, Canada, B) Ganderia, C) Carolinia, D) aggregate peri-Gondwanan realm terranes. 
tectonic activity. Ganderia lacks Ediacaran fossil assemblages, due to either a lack of suitable environments for the recruitment of organisms or conditions favorable to preservation. Carolinia strata contain Ediacaran macrofossils in the terminal Ediacaran (North Carolina, USA: Cid and Floyd Church Formations), when preserved rock volume is at a maximum (Fig. 4B; Weaver et al., 2006). As with Avalonia, low total rock volume and a volume flux dominated by proximal tectonic activity in Ganderia and Carolinia overprints any potential quantitative signature of Gaskiers glaciation. Despite relatively limited preserved rock volume from the Ediacaran of Avalonia, Ganderia, and Carolinia, the stratigraphic records of these terranes contribute to our understanding of the active volcanic margin of Gondwana throughout the Ediacaran, a condition which led to a rock record in these regions that is dominated by local tectonic activity (Figure $3 \mathrm{~B}, \mathrm{C}, \mathrm{D})$.

\section{Western Laurentia}

The Ediacaran of Western Laurentia (W Laurentia) is dominated by the Windermere Supergroup (WSGp) and its correlatives, which stretch from the Sonora region of northwest Mexico to northern Alaska (Fig. 1C; Ross, 1991; Yonkee et al., 2014). Ediacaran sediments of the Mackenzie, Wernecke, and Ogilvie mountains in northwestern Canada, Death Valley, USA, and the Sonora region of Mexico preserve multiple occurrences of macrofossil assemblages and signatures of the Shuram-Wonoka carbon isotope anomaly (Corsetti and Kaufman, 1994; Narbonne et al., 1994; McMenamin, 1996; Corsetti and Hagadorn, 2000; James et al., 2001; Corsetti and Kaufman 2003; Hurtgen et al., 2004; Sour-Tovar et al., 2007; Bergmann et al., 2011; Macdonald and Cohen, 2011; Petterson et al., 2011; Verdel et al., 2011; Loyd et al., 2012; Macdonald et al., 2013; Smith et al., 2016b; Smith et al., 2017; Eyster et al., 2018; Witkosky and Wernicke, 2018; Moynihan et al., 2019; Hodgin et al., 2021). Neoproterozoic through early Cambrian strata of W Laurentia record signals of protracted Rodinia rifting and the development of a lower Paleozoic passive margin (Ross, 1991; Cecile et al., 1997; Lund, 2008; Yonkee et al., 2014; Moynihan et al., 2019). However, the overall tectonic setting of $\mathrm{W}$ Laurentia during the Cryogenian through early Cambrian is a matter of ongoing debate, due in part to a relative lack of direct geochronologic controls in this volcanicpoor tectonic realm (Figs. 2,4A). Uncertainty has largely involved the timing of regional Rodinia rifting, whether there was one or two rift-to-drift transitions from the latest Neoproterozoic to the Middle Cambrian, and the timing of the development of a passive margin (Stewart, 1972; Christie-Blick and Levy, 1989; Ross, 1991; Dalrym- ple and Narbonne, 1996; Colpron et al., 2002; Ross and Arnott, 2007; Post and Long, 2008; Macdonald et al., 2012; Yonkee et al., 2014; Strauss et al., 2015; Moynihan et al., 2019; Brennan et al., 2020; Brennan et al., 2021).

Early Ediacaran (635-585 Ma) W Laurentia rock volume flux is characterized by a comparatively low volume of rock dominated by mud-size sediments (Fig. 4A). There is an increase in the volume of sediments and a shift to sand and carbonate dominated composition at $\sim 585$ Ma. The latest Ediacaran ( 555-541 Ma) in W Laurentia exhibits relatively low preserved rock volume dominated by sand-size sediments and a terminal Ediacaran low that is consistent with an extensive hiatus obscuring the Ediacaran-Cambrian boundary in this tectonic realm (Yonkee et al., 2014). Compared to the other terranes and realms that make up the Ediacaran of North America, carbonates make up a high proportion of $\mathrm{W}$ Laurentia rock volume flux. Volcaniclastic sediments and igneous rocks are rare in W Laurentia sequences, though there is an increase in the area of plutonic units during the latter half of the Ediacaran. A significant carbonate volume increase in the upper Ediacaran of W Laurentia at $\sim 585$ Ma signifies increasing accommodation along the continental margin (Fig. 4A). Increased accommodation would likely have been caused by subsidence driven transgression, perhaps indicating continental separation along at least a portion of the $\mathrm{W}$ Laurentia margin during the mid-late Ediacaran.

Of the tectonic realms/terranes discussed in this study, W Laurentia strata likely have the greatest potential to preserve signals of global geologic processes (such as that of glaciation) due to its overall size and a relative lack of proximal tectonic overprints. While no unambiguously glacially influenced sediments of Ediacaran age are known from W Laurentia, there is a decrease in rock volume that coincides with the $\sim 580$ Ma Gaskiers glaciation (Fig. 4A). This could indicate global glacioeustatic influence on the accumulation of the sedimentary record at this time. It is likely that any ice sheets present during deposition of the Gaskiers Formation were centered on continents other than Laurentia, much like Gondwanan focused ice sheets during the LPIA (Montañez and Poulsen, 2013; Kent and Muttoni, 2020). Deposition of rock units bearing Ediacaran macrofossils in western Laurentia coincides with an overall sustained rise in rock volume and an increase in carbonate volume from $\sim 575$ $550 \mathrm{Ma}$; macrofossil-bearing rock units terminate during decreased rock volume at $\sim 550 \mathrm{Ma}$ (Fig. $4 \mathrm{~A}$ ). Increases in carbonate volume at $\sim 588,580,565$, and 553 Ma likely indicate marine transgression of western Laurentia. 


\section{Southeastern Laurentia}

Ediacaran strata of the southeastern Laurentian (SE Laurentia) realm form a chain of exposures currently stretching from eastern Labrador, Canada to the northcentral portion of Georgia, USA (Fig. 1C). Stratigraphy of SE Laurentia is generally split by its encompassing physiographic province (i.e., Blue-Ridge and Piedmont), or is simply referred to as "Laurentia" when discussed in relation to peri-Gondwanan terranes such as Avalonia (Hibbard et al., 2007; Pollock et al., 2009). NeoproterozoicPaleozoic successions of SE Laurentia typically contain metasediments and have fewer geochronologic constraints due to deformation during tectonic events throughout Pangea's assembly and rifting (Rankin, 1975; Thomas, 1991; Hatcher, 2010; Bailey et al., 2017; Waldron et al., 2019; van Staal et al., 2020). SE Laurentia's quantified Ediacaran rock record predominantly reflects midEdiacaran proximal tectonic activation of a passive Laurentian margin with low preserved rock volume before 590 Ma (Fig. 4B). After 590 Ma rock volume continuously increases, a trend that proceeds across the EdiacaranCambrian boundary. Volcanics, sand-size sediments, and $\geq$ pebble-size sediments dominate the initial rise in volume flux but give way to an increasing proportion of mud-size sediments, signaling a transition from proximal sediment sources to more distal sediment sources in the late Ediacaran. Similar to W Laurentia, the Neoproterozoic SE Laurentian margin is associated with Rodinia rifting and a rift-to-drift transition that is thought to have occurred sometime in the early Cambrian (Hatcher et al., 2007; Hatcher, 2010). In this context, our results suggest an initiation of SE Laurentia rifting in the midEdiacaran. Unlike the W Laurentian realm, SE Laurentia does not exhibit a decrease in rock volume at the terminal Ediacaran and increased carbonate flux suggests that there was increasing accommodation, perhaps due to subsidence of the continental margin after initial rifting. Like Ganderia, SE Laurentia lacks Ediacaran fossil assemblages, due to either a lack of suitable environments for the recruitment of organisms or conditions favorable to preservation.

The Fauquier Fm. (Virginia, USA) contains carbonates bearing a carbon isotope excursion that has been correlated with the Shuram-Wonoka anomaly and interpreted as a cap carbonate overlying a diamictite horizon, potentially of Gaskiers age or a separate, younger glaciation (Hebert et al., 2010). However, there is little evidence of Ediacaran glaciated sediments in other SE Laurentia successions and any quantitative signature of glaciation that might have been present is overwritten by proximal tectonic activity. (Fig. 4B).
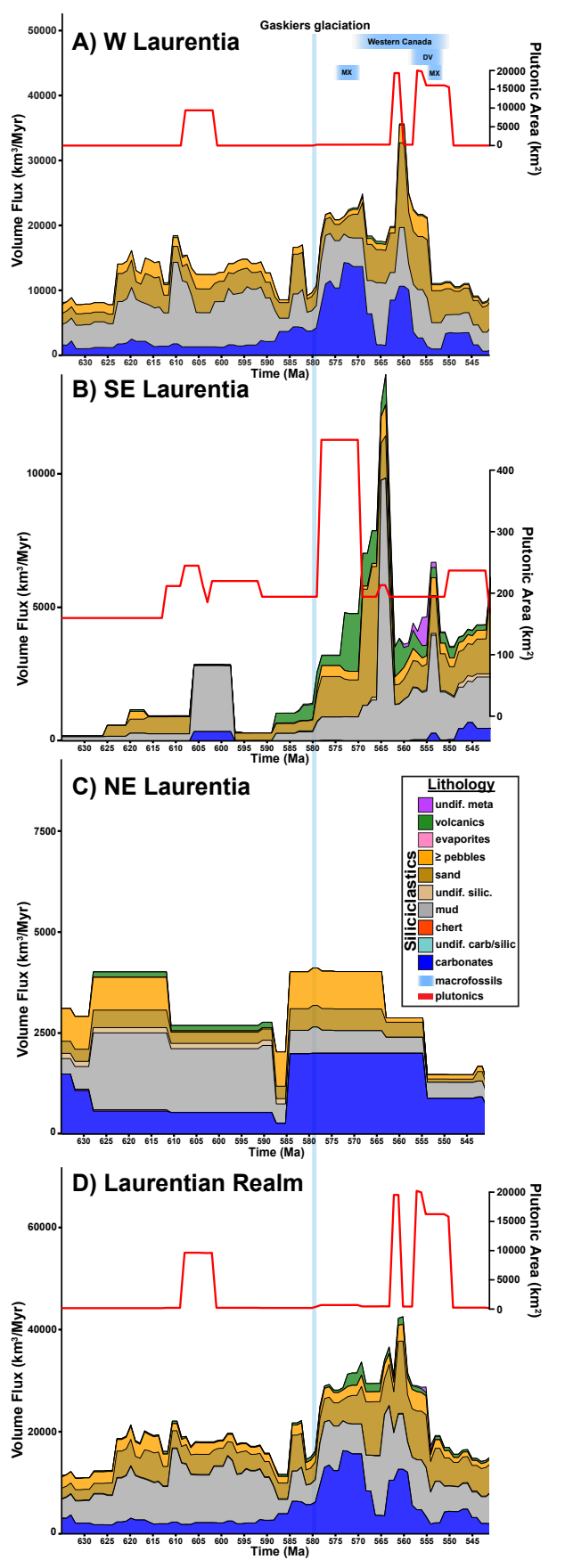

Figure 4: Individual plots of calculated volume flux $\left(\mathrm{km}^{3} / \mathrm{Myr}\right)$ divided by gross lithologic characteristics and calculated areas of Ediacaran age plutonics for each Laurentian tectonic realm from the mesostrat dataset. The Gaskiers glacial horizon and Ediacaran macrofossil occurrences have been highlighted for each terrane. A) NE Laurentia (Nunavut, Greenland and Svalbard), B) SE Laurentia; NC = North Carolina, USA, C) W Laurentia; $\mathrm{DV}=$ Death Valley, USA, MX = Sonora Region, Mexico, and D) aggregate Laurentian realm terranes. 


\section{Northeastern Laurentia}

Northeastern Laurentia (NE Laurentia) is a composite realm of Ediacaran strata from northeastern Nunavut (Canadian Arctic Islands), northern and eastern Greenland, and Svalbard (Fig. 1A-B). Detailed studies of the tectonic affinities of NE Laurentia Neoproterozoic rocks are limited due to difficult field accessibility, a lack of outcrops (Harrison, 1995; Dewing et al., 2004; Beranek et al., 2013), few geochronologic constraints (Fig. 2; Beranek et al., 2013; Willman et al., 2020), and deformation during both the Caledonian orogeny (Ordovician-Early Devonian) and Eocene (Beranek et al., 2013). Exposed ancient strata from Ellesmere island of Nunavut to northeastern Greenland are known colloquially as the Franklinian Basin and Eastern Greenland to Svalbard Neoproterozoic strata are interpreted as Caledonian fragments. These strata are thought to represent a passive margin during the Ediacaran and Cambrian that formed from Rodinia rift related Cryogenian ( $\sim 720 \mathrm{Ma})$ continental flood basalts (Dewing et al., 2004; Denyszyn et al., 2009; Bédard et al., 2012; Beranek et al., 2013). A comparatively low rock volume and high proportion of carbonates supports interpretations of NE Laurentia as a passive margin during the Ediacaran, though increased rock volume with a high proportion of $\geq$ pebble-size sediments at $\sim 585-563$ Ma suggests proximal topographic relief (Fig. 4C). The Shuram-Wonoka excursion has recently been identified in carbonates of northern Greenland in addition to Doushantuo-like phosphatized microfossils (Willman et al., 2020). While no definitive conclusions can be drawn with so few geochronologic constraints, there appears to be no quantitative signature of glaciation associated with the Gaskiers interval in NE Laurentia.

\section{Aggregate Ediacaran System Results}

Median duration (Myr), thickness (m), and simple sedimentary rates (m/Myr) of unconformity-bounded intervals of rock (UBI) in this study and from the comprehensive North American Macrostrat database are compared in Fig. 5. One of the differences in this Ediacaran-centric dataset is an overall decrease in the median duration and thickness estimates for Ediacaran strata, revisions that have made this compilation of the Ediacaran more comparable to the Macrostrat Phanerozoic data. This reflects an overall increase in the resolution of our new compilation and the many recent advances that have been made in Ediacaran correlation and geochronology (Fig 5A,B). The sharp decrease in the median duration of UBIs at $\sim 585 \mathrm{Ma}$ is generally consistent with increasing geochronologic and biostratigraphic control in upper Edi- acaran strata (Fig 5A). However, median thickness also increases after a nadir in the mid-Ediacaran, leading to increasing median sedimentation rate in rock units above the Gaskiers horizon (Fig. 5).

In both this study's dataset and the original Macrostrat dataset, the UBI and area time series are in broad agreement, though in the new compilation there is an increase in the number of UBIs in the upper Ediacaran that is not reflected by area (Supplementary Fig. S1). This is due to the influence of the tectonically complex Gondwanan terranes, where common ashes, tuffs, and volcanics in Ediacaran rocks have been used to subdivide sections into shorter duration units, though the areal extent of the columns in that region are comparatively small (Fig. 1-2; Supplementary Fig. S2).

\section{Aggregate Volume Results}

In aggregate, rock volume flux shows an early Ediacaran $(\sim 623 \mathrm{Ma})$ increase after the termination of Snowball Earth glaciations, a fall and sustained low through to the mid-Ediacaran, a sustained increase from $~ 585-544 \mathrm{Ma}$, and a more rapid decrease at $544 \mathrm{Ma}$ that results in a terminal Ediacaran low comparable to the earlier Ediacaran (Fig. 6D). At the largest of scales, this macrostratigraphic pattern is likely the quantitative expression of the rifting of Rodinia and a transition to a continental drift state, setting the stage for Paleozoic transgression and sediment deposition in continental interiors. The initial increase of sedimentary rock volume in the NA combined data (Fig. 6D) at $\sim 585$ Ma coincides with increased volcanic/volcaniclastic rock volume until the sharp decrease in overall rock volume at $\sim 544$ Ma (Fig. 6D), reflecting to a large extent the contribution of terranes later accreted to Laurentia and the southeast margin of the continent (Figs. 3,4). Mud-size sediment dominance in the early Ediacaran may indicate more distal sediment sources, perhaps due to a dearth of proximal topography after Cryogenian glaciation, a lack of accommodation in landward settings and subsequent erosional loss of proximal sediments, overall net progradation, or some combination of these (Fig. 6D). An increasing proportion of non-marine rock volume in the later Ediacaran (Fig. 7) suggests a role for accommodation limitation on Laurentia overall. Higher proportions of sand and $\geq$ pebble-size sediments in addition to increasing non-marine deposition throughout the mid-Ediacaran ( 590-575 Ma) suggests more proximal sediment-generating sources, possibly associated with tectonic uplift in the southeast part of the continent (Figs. 6D, 7). Carbonate volume pulses, most prominently developed in western Laurentia, indicate decreases in siliciclastic input, likely caused by subsidence-induced marine transgression. Notably, the 
cap carbonate phase of the earliest Ediacaran does not exhibit a marked increase of carbonate volume or area, though there is an increased proportion of carbonate volume (Figs. 6D, 8A,B,C). This may reflect a lack of accommodation in continental settings, the destruction of early Ediacaran depositional sequences, or a combination of these. The terminal Ediacaran ( 544-541 Ma) records a sharp drop in preserved rock volume (Fig. 6D) and a return to early and middle Ediacaran-like ratios of carbonate to clastic sediments, suggesting filling of available accommodation and possibly a minor drop in baselevel.

The number of units that contain macrofossils increases with increasing rock volume at $\sim 580$ Ma before undergoing a decrease that coincides with the terminal Ediacaran drop in preserved rock volume at $\sim 544 \mathrm{Ma}$ (Fig. 6 C,D). While direct geochronologic constraints on Ediacaran fossiliferous units are rare (Xiao and Narbonne, 2020), units bearing the earliest Ediacaran-type macrofossils within regions (e.g., Avalonia and W Laurentia) are consistently correlated with units bearing the Shuram-Wonoka excursion above the Gaskiers horizon, as reflected in the age model presented in this study (Fig. 6; Macdonald et al., 2013).

\section{Carbon Isotope Compilation Results}

A total of 5,410 individual stable carbon (and oxygen) isotopic measurements from nine regions were compiled from North America, representing what we believe to be a complete accounting of published results (Fig. 1, 6A). For reference, schematics of key stratigraphic columns are plotted on the same time series as the carbon isotope values (Fig. $6 \mathrm{~B}) \cdot \delta^{13} \mathrm{C}$ measurements from the 'cap carbonate' at the base of the Ediacaran vary significantly, ranging from $\sim+9 \%$ to $-9 \%$. The lower to middle Ediacaran has few measurements due in part to lower volumes of carbonate, but it is evident that average $\delta^{13} \mathrm{C}$ measurements tend to climb, with some locations reaching as high as $\sim 11 \%$ by the middle Ediacaran (Fig. $6 \mathrm{~A})$. A decrease to a minimum of almost $-14 \%$ from a preceding period-high in $\delta^{13} \mathrm{C}$ marks the Shuram-Wonoka anomaly in NA. Interestingly, the anomaly coincides with an increase in total rock volume, an increase in the proportion of volcanics, the greatest increase in carbonate volume observed during the Ediacaran, an increase in stratigraphic units containing macrofossil occurrences, and an increase in the proportion of carbonates identified as limestone. A subsequent smaller but otherwise similar pulse in the volume and composition of carbonates at $\sim 565 \mathrm{Ma}$ is not associated with a similar coordinated drop in carbon isotope values, though some locations do exhibit negative excursions associated with this carbonate pulse.

The timing of the Shuram-Wonoka that emerges in this analysis generally agrees with current constraints (Fig. 4 of Rooney et al., 2020). $\delta^{13} \mathrm{C}$ recovers and 'stabilizes' to generally more positive values by $\sim 568 \mathrm{Ma}$, until another less well-developed negative excursion (possible prelude to the Basal Cambrian Isotope Excursion) begins during the terminal Ediacaran (Fig. 6A). $\delta^{18} \mathrm{O}$ values measured from the same samples were also compiled and there is little discernible temporal trend in the aggregate of these measurements (Fig S3).

It is conceivable that not using carbon isotope stratigraphy to directly inform our correlations prior to constructing the age model has reduced the precision of our model and, therefore, spuriously increased the range of temporal and spatial variability that is observed in $\delta^{13} \mathrm{C}$ (Fig. 6A). However, given the large degree of $\delta^{13} \mathrm{C}$ variability observed throughout the entire Ediacaran and from location to location across key intervals, we suspect that our synthesis is a reasonably accurate reflection of variability in $\delta^{13} \mathrm{C}$ at this scale.

\section{Ediacaran-Phanerozoic Comparison Results}

Area and volume flux for the Ediacaran compilation, measured in $\mathrm{km}^{2}$ and $\mathrm{km}^{3} / \mathrm{Myr}$ respectively, are plotted adjacent to Ediacaran-normalized Phanerozoic Macrostrat sediment flux in Fig. 8. In keeping with previous results, which identified a large, stepwise increase in surviving sediment quantity from the Neoproterozoic to the Cambrian (Ronov et al., 1980; Peters and Gaines, 2012; Peters and Husson, 2017; Keller et al., 2019), this study finds that Ediacaran rock volume is much diminished relative to comparable intervals in most of the Phanerozoic. We do identify a rise in preserved rock volume in the upper Ediacaran, but the large increase to Paleozoic-like quantities takes place during the Cambrian and after a terminal Ediacaran decline (Fig 8A,B). The composition of Ediacaran sediments further distinguish them from the anteceding Paleozoic, with the Ediacaran exhibiting increased proportions of volcanics and decreased proportions of carbonates (Fig. 8C). This overall motif of low rock quantity and relative proportions of lithologies is not repeated until the late Permian through Triassic (Fig. $8)$.

\section{Gaskiers Glaciation and Volume Results}

The total rock volume flux of Ediacaran sediments from North America does not show a marked volumetric or lithologic shift associated with the Gaskiers glaciation (Figs. 6D, 8A), with the exception of a minor decrease of rock volume before $580 \mathrm{Ma}$ in W Laurentia (Fig. 4A). 


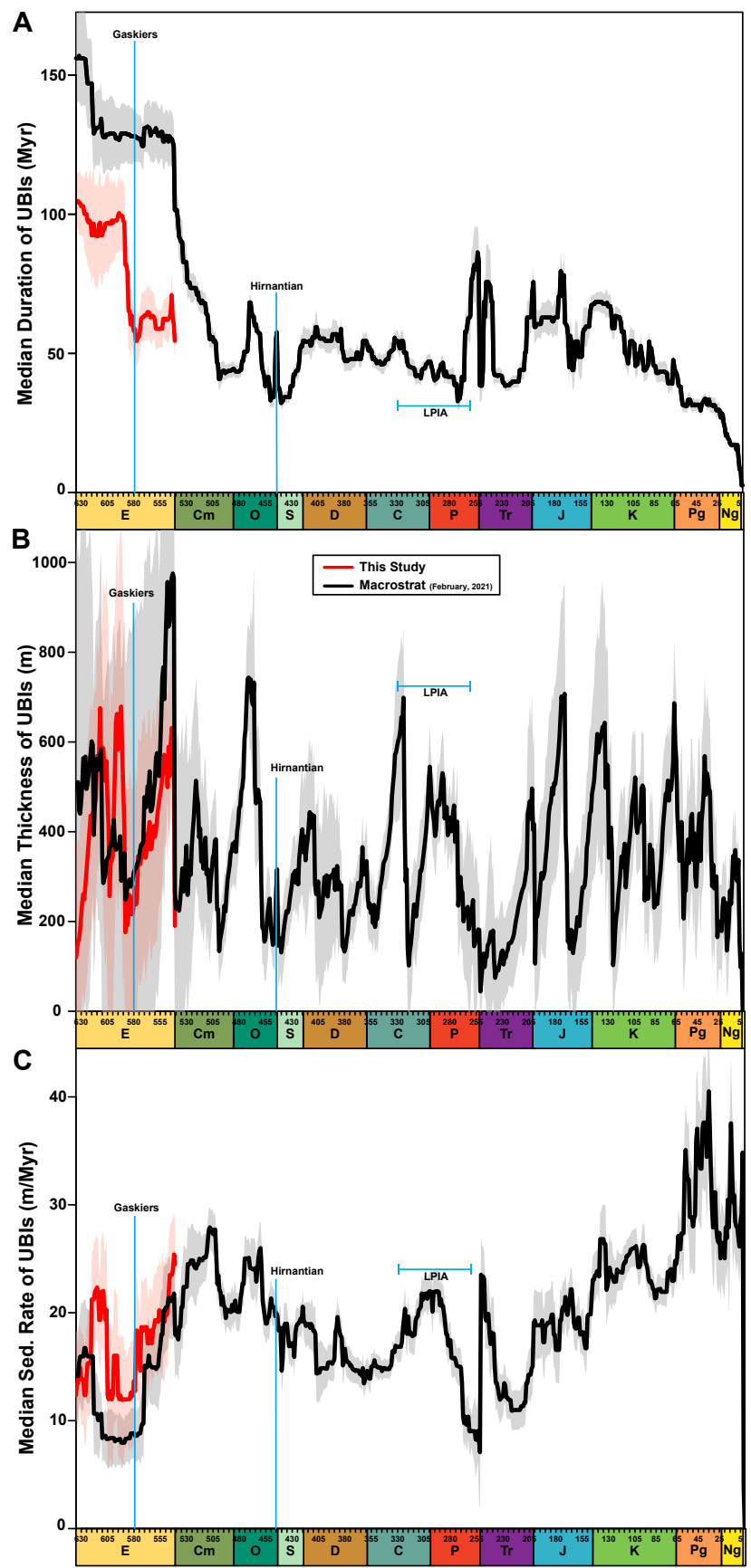

Figure 5: A) Median duration (Myr) of UBI from NA Ediacaran and Phanerozoic strata, B) Median thickness (m) of UBI from NA Ediacaran and Phanerozoic strata, and C) Median sedimentary rate (m/Myr) of UBI from NA Ediacaran and Phanerozoic strata. Red lines are calculated from the dataset compiled for this study and black lines are calculated from Macrostrat's pre-existing dataset. Colored envelopes represent bootstrap resampled error at one standard deviation for the mesostrat data (red) and Macrostrat data (gray). 'Gaskiers' refers to the Gaskiers glaciation event, timing is from $\mathrm{Pu}$ et al., 2016. 'Hirnantian' refers to the end-Ordovician glacial event, timing is from Creveling et al., 2018. 'LPIA' refers to the Late Paleozoic Ice Age, timing is from Kent and Muttoni, 2020. Mesostrat dataset duration and thickness of UBI is lesser than Macrostrat's, indicating a resolution increase. Both the median sedimentary rate and the median thickness have decreases that coincide with the Gaskiers glaciation horizon. Hirnantian and LPIA glaciations are southern hemisphere/Gondwanan focused events that have associated decreases in UBI duration and thickness of Laurentian gap bound packages, highlighting their global impact. 
This could be a potential signature of glacioeustatic sea level fall. However, the decrease in rock volume has a relatively short duration and could be more reflective of a general lack of geochronologic constraints for the Ediacaran at this time. Decreases in median thicknesses and accumulation rates of UBIs do coincide with the timing of the Gaskiers glaciation (Fig. 5B,C) and there is a modest coarsening of the siliciclastic component (Fig. $6 \mathrm{D})$. The timing of the Gaskiers glaciation coincides with early stages of the Shuram-Wonoka excursion, but the nature of its relationship to this anomaly is unknown.

\section{DISCUSSION}

The last section of the Ediacaran chapter in the Geologic Time Scale 2012 asks the question, "Ediacaran - Last period of the Proterozoic or first period of the Phanerozoic?" (Narbonne et al., 2012). The large increase in rock volume and area that occurs across the Ediacaran-Cambrian boundary and its changing lithological composition may provide a rock record-grounded basis for answering that question (Fig. 8), at least in North America. Ediacaran rock volume is decisively low and its composition quite different in comparison to the Cambrian and remainder of the Paleozoic (Fig. 8B). Ediacaran patterns of preserved rock volume and lithology do, however, bear some resemblance to the end-Permian through early Mesozoic. Thus, from the point of view of macrostratigraphy, the Ediacaran as the terminal period in a transition between eras is appealing.

The Wilson cycle of opening/closing ocean basins and supercontinent breakup and formation exerts a first order control on Phanerozoic continental sedimentation patterns, and that is evident here, as it is in all other compilations of aggregate rock properties at Phanerozoic and longer timescales (Wilson, 1966; Ronov et al., 1980; Cloetingh et al., 1984; Peters 2005, 2006; Meyers and Peters, 2011; Peters and Husson, 2017; Zaffos et al., 2017; Husson and Peters, 2018). Broadly speaking, the opening of ocean basins results in sediment accumulation on continental margins for several reasons, including enabling the thermal subsidence of rifted margins. Signals of at least regional subsidence are discernible throughout the Phanerozoic macrostratigraphy of North America. For example, Cretaceous strata of North America exhibit increased area associated with transgression, but it is also associated with a more pronounced rock volume increase (Fig. 8A,B), a reflection of the enhanced subsidence in western NA occurring in response to crustal flexure and the effects of the subducting Farallon slab and spreading center subduction on dynamic topography (Gurnis, 1993; DeCelles, 2004; Liu et al., 2010). The
Carboniferous exhibits a similar signature of increased rock volume flux with a lesser magnitude area increase (Fig. 8A,B), a signature of crustal flexure along the ancient Appalachian mountains during Pangea's assembly (Wilson, 1966, Nance et al., 2008; van Staal et al., 2009; Hibbard et al., 2010, van Staal et al., 2012). In contrast, Cambrian and Ordovician strata have a significantly increased area, reaching an all-time high in the Phanerozoic, but that is not associated with a high in rock volume flux (Fig. 8A,B). This is because whatever induced the transgression that flooded most, if not all of Laurentia in the Cambrian, and even more so during the Ordovician, left behind a relatively thin, widespread, carbonate-rich veneer of sediment, presumably because of a lack of subsidence (and/or sediment supply).

The upper Ediacaran ( 590-541 Ma) stratigraphic record bears some resemblance in pattern and duration to Phanerozoic Sloss sequences (Meyers and Peters, 2011). The muted increase of total column area in the upper Ediacaran compared to the coincident increase in volume flux (Fig. 8A,B) may be indicative of margin subsidenceinduced accommodation formation, with comparatively limited flooding of the continent. Based on the overall similarity in pattern and timescale, and a possible link to marginal continental dynamics, we suggest that the Ediacaran rock record contains a Sloss sequence-like signal comparable to the macrostratigraphy-redefined Sloss Sequences of Meyers and Peters (2011). For convenience, we refer to the Ediacaran sequence as the 'Mackenzie Sequence' (Fig. 8A; named after the Ediacaran carbonates of the Mackenzie Mountains in NW Canada, where the rise and fall in rock quantity and carbonate fractions thereof are well expressed).

From the point of view of macrostratigraphic quantities describing the physical, spatial-temporal variability of the rock record, the Ediacaran System is well placed at the boundary with the Sauk Sequence and as a transition between the Neoproterozoic and Phanerozoic eons (Landing, 1994). The closest quantitative analogue to the Ediacaran system in North America, from the point of view of macrostratigraphic quantities describing rock quantity and composition, and likely overall tectonic state, is the Triassic (Fig. 8).

\section{The Shuram-Wonoka anomaly and marine transgression}

The Shuram-Wonoka anomaly is the largest magnitude marine carbonate $\delta^{13} \mathrm{C}$ excursion occurring in a series of perturbations observed during the Neoproterozoic ( 720 Ma Garvellach and 650 Trezona anomalies), through the Ediacaran-Cambrian (Basal Cambrian Isotope Ex 


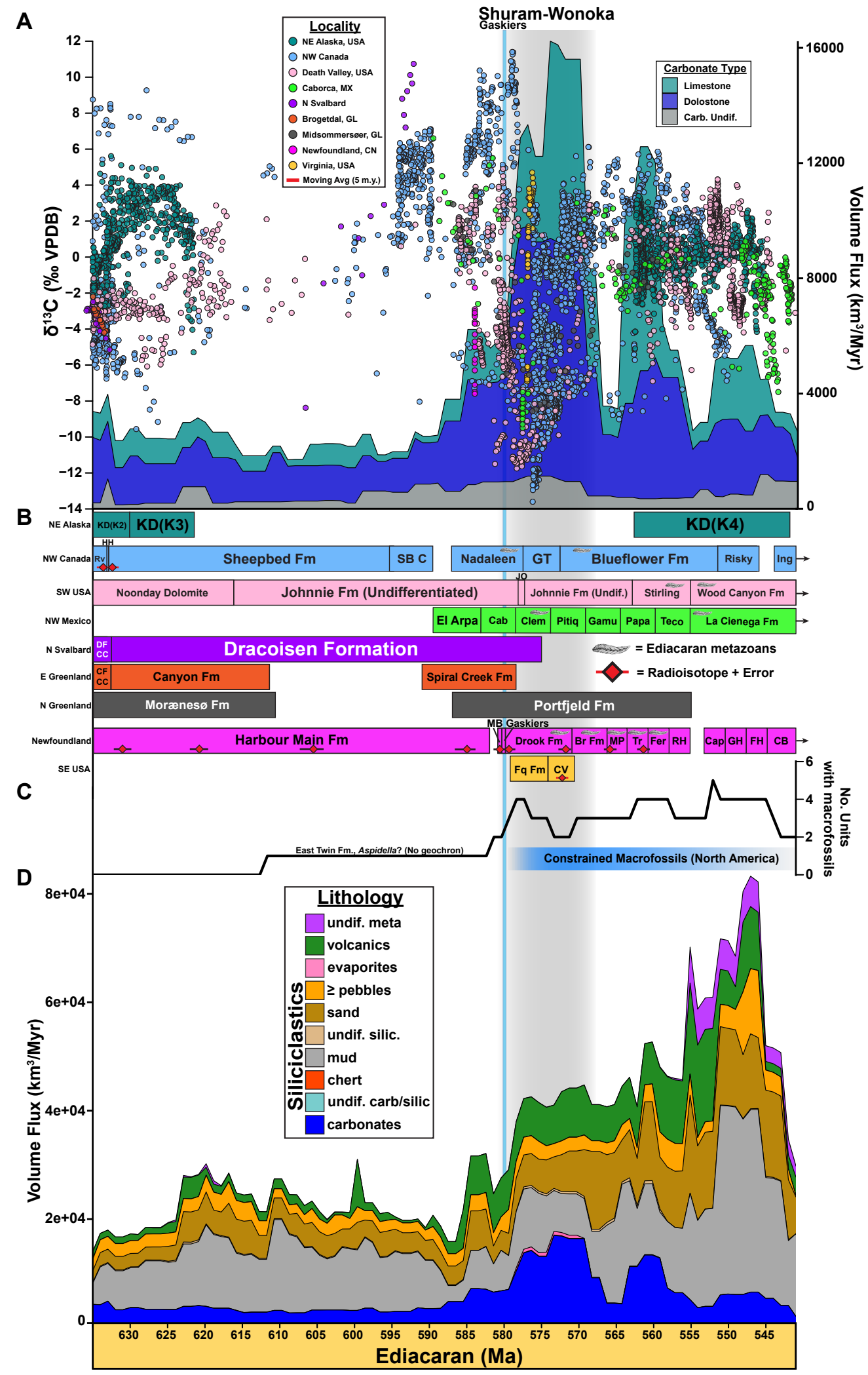

Figure 6: (Continued on following page.) 
Figure 6: Diagnostic chemostratigraphic and lithostratigraphic features of the Ediacaran rock record arranged on the mesostrat age model. A) Compilation of NA Ediacaran $\delta^{13} \mathrm{C}$ values (primary y-axis) measured from carbonates. Points are individual carbon isotope measurements and are colored by the general locality they were sampled from. Alaska: Macdonald et al., 2009, NW Canada: Narbonne et al., 1994; James et al., 2001; Macdonald and Cohen, 2011; Macdonald et al., 2013; Moynihan et al., 2019, British Columbia: Eyster et al., 2018, Death Valley: Corsetti and Kaufman, 1994; Corsetti and Kaufman, 2003; Hurtgen et al., 2004; Bergmann et al., 2011; Petterson et al., 2011; Verdel et al., 2011; Loyd et al., 2012; Smith et al., 2016b; Smith et al., 2017; Witkosky and Wernicke, 2018, Cerro Rajon: Loyd et al., 2012, Hodgin et al., 2021, Brogetdal: Hoffman et al., 2012, Harbour Main: Myrow and Kaufman, 1999, Northern Virginia: Hebert et al., 2010, Midsommersøer: Willman et al., 2020, and Svalbard: Halverson et al., 2005. The secondary y-axis, and backdrop, is the volume flux $\left(\mathrm{km}^{3} / \mathrm{Myr}\right)$ of carbonates from the mesostrat dataset, divided into and colored by their dominant carbonate type. The Shuram-Wonoka anomaly (arranged with the excursion as indicated by the points) and Gaskiers glacial interval are highlighted throughout the figure. B) Key stratigraphic columns from which the compiled carbon isotope values have been measured. Each column is labeled with representative radioisotopic dates, approximate stratigraphic position of macrofossil occurrences, and formation names. $\mathrm{KD}=$ Katakturuk Dolomite, K2-K4 = informal Katakturuk units, Rv = Ravensthroat, HH = Hayhook, Sb $=$ Sheepbed, SB C = Sheepbed Carbonate, GT = Gametrail, Ing = Ingta, JO = Johnnie Oolite, Cab = Caborca, Clem = Clemente, Pitiq = Pitiquito, Gamu = Gamuza, Papa = Papalote, Teco $=$ Tecolote, DF CC $=$ Dracoisen Fm Cap Carbonate, CF CC = Canyon Fm 'Cap Carbonate', MB = Mall Bay, Br = Briscal, MP = Mistaken Point, Tr $=$ Trepassey, Fer = Fermeuse, RH = Rocky Harbour, Cap = Cappahayden, GH = Gibbett Hill, FH = Ferryland Head, $\mathrm{CB}=$ Cape Ballard, $\mathrm{Fq}=$ Fauquier, and $\mathrm{CV}=$ Catoctin Volcanics. Key stratigraphic columns (composite) are derived from localities in references for carbon isotope data. Accompanying $\delta^{18} \mathrm{O}$ can be found in supplement (Fig. S3). Radioisotopic dates of key stratigraphic columns are from Benus (1988), Krogh et al. (1988), Southworth et al. (2009), Rooney et al. (2015), Pu et al. (2016), Canfield et al. (2020), and Rooney et al. (2020). C) Number of units that contain Ediacaran macrofossil occurrences from the mesostrat dataset. Definitively constrained macrofossil occurrences are as old as 579 Ma on North America (Narbonne et al., 2012), though formations that had ages based dominantly on Ediacaran macrofossil occurrences were not enforced in building the age model. 'Constrained macrofossils' indicates Ediacaran strata in which macrofossils are found on NA. D) Calculated volume flux ( $\left.\mathrm{km}^{3} / \mathrm{Myr}\right)$ of the Ediacaran divided by gross lithologic categories from the mesostrat dataset.

cursion), and extending into the early Paleozoic (Cramer and Jarvis, 2020). It has been proposed that a $\delta^{13} \mathrm{C}$ gradient existed between shallow marine shelf environments and deeper marine settings along Ediacaran shelf-to-slope profiles of continental margins (Li et al., 2010; Macdonald et al., 2013; Schrag et al., 2013; Cui et al., 2015; Cui et al., 2017; Shields et al., 2019; Husson et al., 2020; Laakso and Schrag, 2020; Li et al., 2020). A globally synchronous migration of a $\delta^{13} \mathrm{C}$ gradient may have been a key mechanism behind the initial positive excursion and subsequent negative drop that is a signature of the Shuram-Wonoka anomaly in marine carbonates. Global marine transgression during the Shuram-Wonoka, evidenced here by a very large (more than quadrupling) and relatively abrupt (c.a., $10 \mathrm{Myr}$ ) increase in carbonate volume and area (Figs. 4A, 6A,D, 8A), is consistent with sequence stratigraphic interpretations (Christie-Blick et al., 1995; Le Guerroué et al., 2006; Macdonald et al., 2013; Cochrane et al., 2019). Thus, our data support the broad expansion of carbonate shelf area, likely caused by marine transgression, as an environmental correlate of the Shuram-Wonoka anomaly.

\section{The Ediacaran fossil record and strati- graphic paleobiology}

Macroevolutionary trends have long been recognized as correlating with preserved sedimentary rock volume throughout geologic time (Raup, 1972; Raup, 1976). A matter of continuing debate is whether the correlation between biodiversity and preserved rock quantity is evidence for preservation bias that has distorted patterns in the fossil record or is instead a signal of geological processes exerting direct or indirect controls on the timing of biological evolution and physical environmental changes that affect the pattern of sedimentation (Newell, 1959). The latter is known as the "common-cause" hypothesis (Crampton et al., 2003; Peters, 2005; Peters and Heim, 2011a; Peters et al., 2013; Holland, 2017; Husson and Peters, 2018; Nawrot et al., 2018). The appearances and disappearances of Ediacaran-type macrofossils are subject to this same debate (Seilacher, 1984; Amthor et al., 2003; Johnston et al., 2012; Laflamme et al., 2013; Cohen and Macdonald, 2015; Darroch et al., 2015; Sperling et al., 2016; Bowyer et al., 2017; Darroch et al., 2018; Tarhan et al., 2018; Gehling et al., 2019), particularly 
given their appearance around the Gaskiers horizon $(\mathrm{Pu}$ et al., 2016; Xiao and Narbonne, 2020) and the ascending limb of Ediacaran marine rock quantity, as well as in their disappearance during the terminal Ediacaran decline in rock quantity (Fig. 6C,D).

Enigmatic taxonomy and the overall rarity of fossil occurrences makes it particularly difficult to measure biological diversity in the Neoproterozoic. However, Ediacaran eukaryotes have been shown to have increased within-assemblage diversity compared to the preceding Cryogenian and Tonian (Cohen and Macdonald, 2015). Counts of geologic units that contain Ediacaran macrofossils in North America serve as a coarse proxy for either the number of depositional environments capable of supporting the earliest known assemblages and/or our sampling thereof (Fig. 6B,C). Interestingly, units that contain the oldest known Ediacaran macrofossils are correlative with periods of increased preserved rock volume in their respective terranes/realms (Figs. 3A, 4A,B). In aggregate, units that contain Ediacaran macrofossils have initiations correlative with the onset of marine transgression at $\sim 585 \mathrm{Ma}$ (Fig. 6). Subsidence driven marine transgression could have functioned as a common-cause mechanism, driving accommodation-based expansion of preserved rock volume and increased habitable ecospace for the oldest known Ediacaran macroscopic organisms. Increased burial and long-term sequestration of carbon associated with continental flooding in W Laurentia (Fig. $4 \mathrm{~A}$; also evidenced by the global presence of carbonates from which the Shuram-Wonoka is identified around this time) may have contributed to increased $p \mathrm{O}_{2}$ during the late Ediacaran (Canfield et al., 2007; Sahoo et al., 2012; Ling et al., 2013; Partin et al., 2013; Sperling et al., 2013; Sperling et al., 2015b; Lee et al., 2016; Husson and Peters, 2017; Wang et al., 2018; Williams et al., 2019), possibly contributing to the development of more complex macroscopic organisms (Sperling et al., 2013; Mills et al., 2014; Sperling et al., 2015a; Zhang and Cui, 2016; Yang et al., 2018). Alternatively, the coinciding increase in rock units with Ediacaran macrofossils and increased rock volume could simply reflect a shift in the extent of facies suitable for fossil preservation and sampling. Disappearance of Ediacaran macrofossils in North America coincides with decreases in preserved rock volume (Figs. 3A, 4A, 6C,D), perhaps indicating a regression-based influence on both preserved rock volume and available habitable ecospace or associated environmental shifts that result in a decrease in the extent and abundance of shelf life. Alternatively, it could reflect a facies-control on sampling bias or destruction of terminal Ediacaran sediment cover during extensive Cambrian transgression (Peters and Gaines, 2012; Shahkarami et al., 2020). More
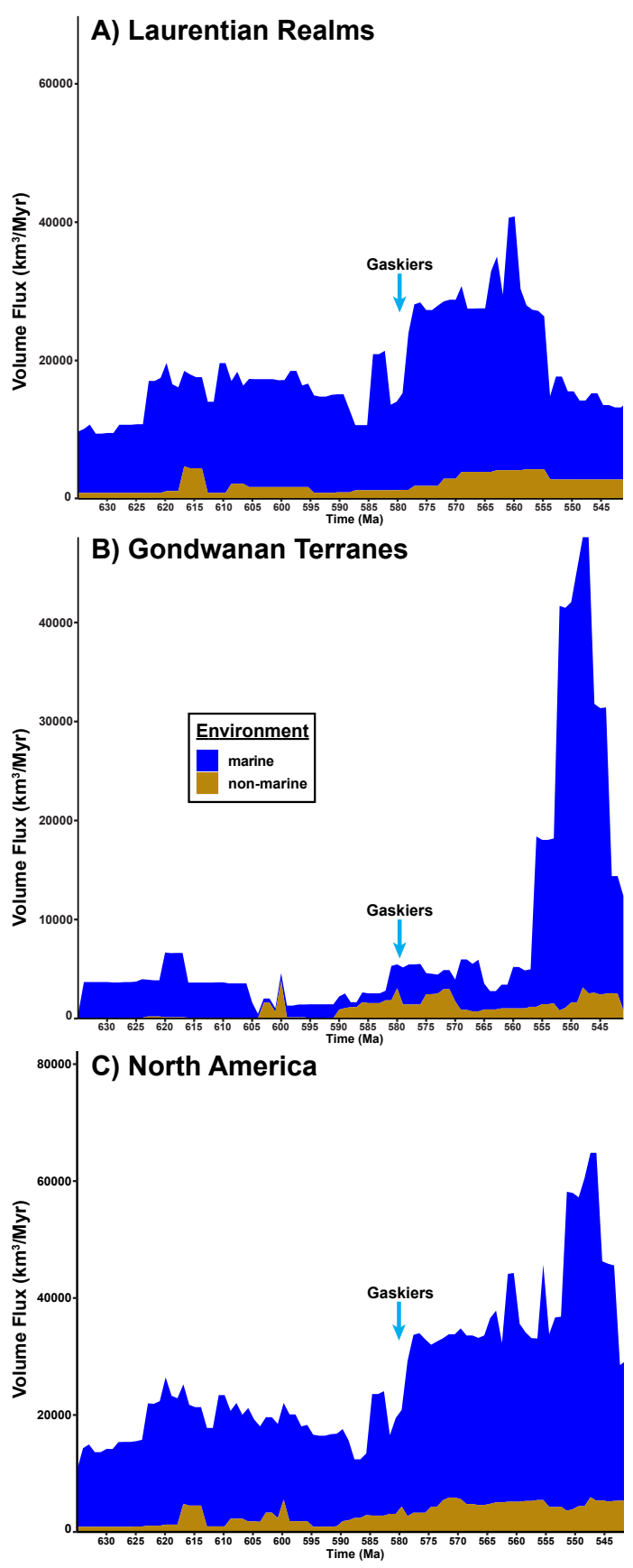

Figure 7: Individual plots of calculated sediment volume flux $\left(\mathrm{km}^{3} / \mathrm{Myr}\right)$ divided by gross depositional environment (marine vs. non-marine). Of note is the rise in the volume of non-marine sedimentary deposits throughout the Ediacaran, and the decrease at the terminal Ediacaran, signaling the initiation of Cambrian-type continental flooding. A) Gondwanan terranes aggregate, B) Laurentian realms aggregate, C) North America aggregate. 
detailed data on assemblage-level biodiversity (similar to Cohen and Macdonald, 2015, but with higher resolution for the Ediacaran) and more detailed stratigraphic and environmental context for those fossils and the surrounding unfossiliferous successions will yield further insight into the common cause hypothesis, which finds some support in the convergence of quantitative stratigraphic, geochemical, and biological patterns documented here (Fig. 6).

\section{The Ediacaran and the Great Unconfor- mity}

Ediacaran-age sediments are restricted to the margins of modern North America and were even more marginally located in the context of Laurentia (Fig. 1). CambroOrdovician sediments, by contrast, extend across most of Laurentia's continental area today (Peters and Gaines, 2012; Husson and Peters, 2017; Peters and Husson, 2017) and probably originally covered essentially all of the continent. This difference in sedimentary cover distribution constitutes the most important and distinguishing feature of the Great Unconformity (GUn). Multiple events spanning a long period of time contributed to the crustalscale signatures of continental denudation that are evident among most of the highly heterogeneous rocks beneath the GUn (Flowers et al., 2020). Cryogenian snowball Earth glaciations have been hypothesized to be among the events contributing to that sub-GUn erosion. A more interesting aspect of this hypothesis is that it provided a mechanism for abruptly creating accommodation required for the large increase in the volume (and area) of sediments capping the GUn (Keller et al., 2019). The isostatic aspect of this crustal thinning hypothesis has the advantage of making several testable predictions, including the timing of increasing continental sedimentary coverage after Cryogenian deglaciation. When this is modeled and compared to the original Macrostrat data in North America (Fig 4. of Keller et al., 2019), there is a temporal lag between the predicted and observed expansion of sedimentary cover. Indeed, the glacial denudation model predicts that peak sediment coverage should have occurred during the latest Ediacaran and earliest Cambrian. However, expansion in continental sedimentary coverage was much more protracted; it did not occur before the Middle Cambrian and sediment coverage of North America (and the global extent of shallows seas; Ronov et al., 1980) seems to have continued to expand even into the Ordovician (Fig. 8A).

There are multiple possible explanations for the accommodation-sedimentation timing offset in the Keller et al. (2019) model. One possibility was that sam- pling and/or chronological bias in the original Macrostrat database for North America was grossly misrepresenting the actual volume and extent of Ediacaran-early Cambrian rocks. However, our new higher resolution and up-to-date Ediacaran compilation demonstrates that this is not likely (Supplementary Fig. S1), and even identifies within the Ediacaran a Phanerozoic-like Sloss sequence cycle (Fig. 8). Another possible explanation for the sedimentation lag was that Ediacaran depositional systems may have been sediment starved due to a lack of proximal topography. This might be expected if Cryogenian glaciations essentially "planed off" continental surfaces and pushed large quantities of sediment onto oceanic crust where it was recycled. This would mean large areas of the continents were flooded after deglaciation, but little or no sediment was deposited. The dominance of mud-size sediments early in the Ediacaran is intriguing, but the presence and increasing proportion of non-marine sedimentary deposits throughout the Ediacaran, on the margins of Laurentia, as well as coarser sediment deposition after $585 \mathrm{Ma}$, indicates that such a sediment starvation scenario is unlikely for at least the youngest half of the Ediacaran (Figs. 6D,7). Instead, the weight of evidence suggests that Ediacaran sedimentary systems were accommodation limited, likely due to a lack of continental sedimentary basin formation and broader continental flooding, as may have been the case for much of the preceding Neoproterozoic and Mesoproterozoic.

\section{CONCLUSIONS}

A quantitative, macrostratigraphic perspective on the Ediacaran System in North America provides a geologic framework for analyzing tectonostratigraphic, geochemical, and paleobiologic patterns and comparing them to better-known intervals of the Phanerozoic. There are several striking similarities between the Ediacaran and early Mesozoic of NA that likely reflect a common position in the Wilson cycle and a superimposed Sloss sequence-scale accommodation cycle. The geographic and temporal extent of Ediacaran glaciation and how it relates to first occurrences of macrofossils and $\delta^{13} \mathrm{C}$ trends of marine carbonates remain unclear. There is little signature of Ediacaran glaciation in North American macrostratigraphy, but it is also possible that large ice sheets were located on other continents and left more distinct signatures in those successions and in the higher-order temporal structure of sedimentation than is resolvable by our $\leq$ 3rd $\left(10^{6}\right.$ years $)$ order analysis.

The extent to which the Ediacaran fossil record and apparent timing of initial diversification of animals is overprinted by a rock record related sampling bias is unclear, 


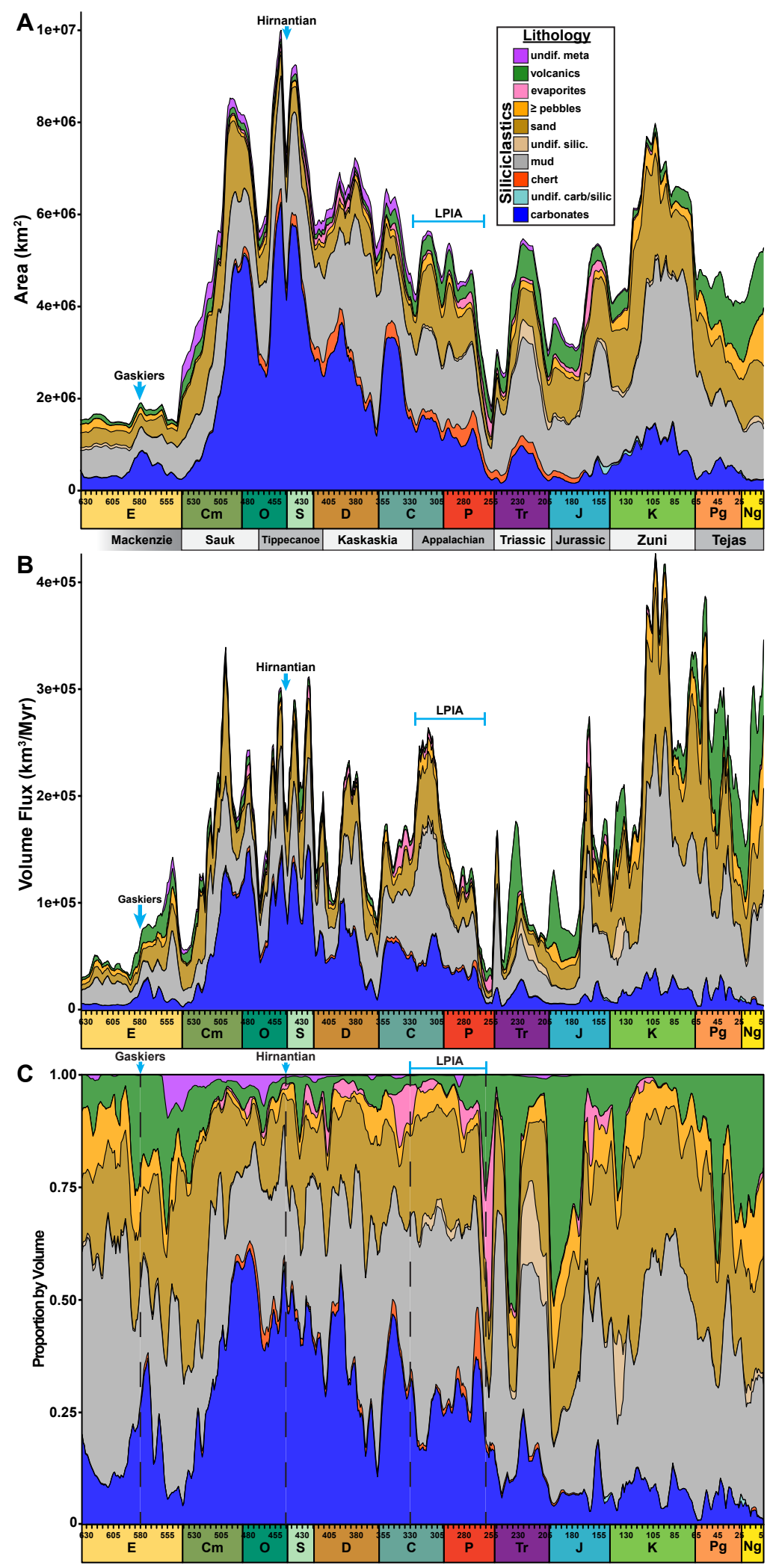

Figure 8: (Continued on following page.) 
Figure 8: Plots of calculated area $\left(\mathrm{km}^{2}\right)$, volume flux $\left(\mathrm{km}^{3} / \mathrm{Myr}\right)$, and the proportion by volume of the Ediacaran (mesostrat; this study) and the Phanerozoic (Macrostrat), divided by gross lithologic characteristics. 'undif. meta' = undifferentiated metamorphic rocks, 'volcanics' = extrusive igneous and volcaniclastic rocks, 'evaporites' = bedded evaporites (e.g. halite), ' $\geq$ pebbles' $=$ siliciclastics with dominant grain size pebbles, 'sand' $=$ siliciclastics with dominant sand grain size, 'undif. silic.' = undifferentiated siliciclastics, 'mud' = siliciclastics with dominantly silt or smaller grain size, 'chert' $=$ chemically precipitated siliceous rocks, 'undif. carb/silic' $=$ undifferentiated mixed carbonate/siliciclastics, and 'carbonates' = chemically precipitated carbonate rocks. Mesostrat (this study) Ediacaran area was scaled to Macrostrat Ediacaran area using the average difference between the area calculations in Supplemental Figure S1. All curves were smoothed using a simple moving average with a 5 Myr window. 'Gaskiers' refers to the Gaskiers glaciation event, timing is from $\mathrm{Pu}$ et al., 2016. 'Hirnantian' refers to the end-Ordovician glacial event, timing is from Creveling et al., 2018. 'LPIA' refers to the Late Paleozoic Ice Age, timing is from Kent and Muttoni, 2020. A) Calculated area $(\mathrm{km} 2)$ of the Ediacaran and Phanerozoic divided by gross lithology characteristics. Sloss sequences with timings as defined in Meyers and Peters, 2011 have been plotted in addition to a suggested 'Mackenzie' sequence for the upper Ediacaran. B) Calculated volume flux $\left(\mathrm{km}^{3} / \mathrm{Myr}\right)$ of the Ediacaran and Phanerozoic divided by gross lithology characteristics. The Ediacaran of NA's estimated area and volume flux is significantly lower than any time in the Phanerozoic except the Permo-Triassic and is followed by a sharp rise across the Ediacaran-Cambrian boundary. C) Calculated proportions of lithologic subdivisions by volume. Note the distinct difference between lithologic proportions of the Ediacaran and subsequent Paleozoic.

but it seems much more likely that there is a common cause that links temporal patterns in sedimentation to the evolution of the biosphere, either directly through something like a species-area effect, or indirectly through its effect on biogeochemical cycling and the protracted rise of oxygen to Phanerozoic levels (Partin et al., 2013; Lee et al., 2016; Husson and Peters, 2017; Wang, et al., 2018; Williams et al., 2019).

Compilations of sedimentary and igneous rocks, assembled over continental and global scales, have made it abundantly clear there are shared global signals carried by most large continental blocks (Ronov et al. 1980; Husson and Peters, 2017). However, each continent, each domain within a continent, and each basin and section within that continent is also, at some level, unique. The extent to which macrostratigraphy for the Ediacaran System of North America contains a global signal remains unknown, but the close correspondence of the biggest increase in shelf carbonate sedimentation in North America and the largest ostensibly global carbon isotope excursion is quite compelling. This suggests that a global signal is likely to be present in these data and that it is likely related to global continental flooding, as it is in the Phanerozoic. The quantitative signature of rock destruction is muted in these data and in the overlying Phanerozoic surviving rock quantities. However, erosion and loss of sediments has clearly occurred, and it is not known to what extent Ediacaran sediments have been lost from the interior regions of North America. However, the presence of thin Cambrian and Ordovician capping sediments over nearly the entire continent constrains the timing of any such loss of Ediacaran deposits; based on the observed distribution of facies and environments, we believe that significant quantities of Ediacaran sediment did not originally extend far beyond the limits that are defined by their current positions along the margins of the continent. However, any Ediacaran sediments deposited on adjacent oceanic crust would have been completely recycled by the end of the Paleozoic. Extension of our effort to other continents, and additional analyses of this dataset that are focused on specific lithological and environmental components of the system, will expand our perspective of the Ediacaran Period in North America and provide an important quantitative chronostratigraphic framework with which to integrate and interrogate proxy records at the dawn of animal life.

\section{ACKNOWLEDGEMENTS}

DCS was supported by funding from the University of Wisconsin-Madison Geoscience Department and through the Morgridge Distinguished Graduate Fellowship. The authors would like to thank the Macrostrat development team and B. Hupp for their feedback on early versions of this study. The authors would also like to thank N. Christie-Blick and an anonymous reviewer for their thorough, constructive comments that greatly improved this paper. Macrostrat infrastructure development supported by US National Science Foundation EAR-1150082 and EarthCube ICER-1440312.

\section{REFERENCES}

Adrain, J.M., Westrop, S.R., Chatterton, B.D., and Ramsköld, L., 2000. Silurian trilobite alpha diversity 
and the end-Ordovician mass extinction: Paleobiology, v. 26(4), p. 625-646.

Ahm, A.S.C., Maloof, A.C., Macdonald, F.A., Hoffman, P.F., Bjerrum, C.J., Bold, U., Rose, C.V., Strauss, J.V., and Higgins, J.A., 2019, An early diagenetic deglacial origin for basal Ediacaran "cap dolostones". Earth and Planetary Science Letters, v. 506, p. 292-307, doi: 10.1016/j.epsl.2018.10.046.

Amthor, J.E., Grotzinger, J.P., Schroder, S., Bowring, S.A., Ramezani, J., Martin, M.W., and Matter A., 2003, Extinction of Cloudina and Namacalathus at the Precambrian - Cambrian boundary in Oman: Geology, v. 31, p. 431-434, doi: 10.1130/00917613(2003)031;0431:EOCANA¿2.0.CO;2.

Bailey, C.M., Spears, A.V., and Marshall, A., 2017, From Laurentia to Iapetus: Traversing the Blue RidgePiedmont terrane boundary in central Virginia, in Bailey, C.M., and Jaye, S., eds., From the Blue Ridge to the Beach: Geological Field Excursions across Virginia. Geological Society of America Field Guide, v. 47, p. 59-75, doi: $10.1130 / 2017.0047(02)$.

Bédard, J.H., Naslund, H.R., Nabelek, P., Winpenny, A., Hryciuk, M., Macdonald, W., Hayes, B., Steigerwaldt, K., Hadlari, T., Rainbird, R., Dewing, K., and Girard, É., 2012, Fault-mediated melt ascent in a Neoproterozoic continental flood basalt province, the Franklin sills, Victoria Island, Canada: Geological Society of America Bulletin, v. 124, p. 723-736, doi: 10.1130/B30450.1.

Benus, A.P., 1988. Sedimentological context of a deep-water Ediacaran fauna (Mistaken Point Formation, Avalon Zone, eastern Newfoundland), in Landing, E., Narbonne, G.M., and Myrow, P., eds., Trace fossils, small shelly fossils and the Precambrian-Cambrian boundary. New York State Museum, New York, Geological Survey Bulletin, v. 463, p. 8-9.

Beranek, L.P., Pease, V., Scott, R.A., and Thomsen, T.B., 2013, Detrital zircon geochronology of Ediacaran to Cambrian deep-water strata of the Franklinian basin, northern Ellesmere Island, Nunavut: implications for regional stratigraphic correlations: Canadian Journal of Earth Sciences, v. 50(10), p. 1007-1018, doi: 10.1139/cjes-20130026 .

Bergmann, K.D., Zentmyer, R.A., and Fischer, W.W., 2011, The stratigraphic expression of a large negative carbon isotope excursion from the Ediacaran Johnnie Formation, Death Valley: Precambrian Research, v. 188(1-4), p. 45-56, doi: 10.1016/j.precamres.2011.03.014.
Bevier, M.L., Barr, S.M., White, C.E., and Macdonald, A.S., 1993, U-Pb geochronologic constraints on the volcanic evolution of the Mira (Avalon) terrane, southeastern Cape Breton Island, Nova Scotia: Canadian Journal of Earth Sciences, v. 30(1), p. 1-10, doi: 10.1139/e93-001.

Billings, E., 1872, On some fossils from the primordial rocks of Newfoundland: Canadian Naturalist and Quarterly Journal of Science, v. 6, p. 465-479.

Bobrovskiy, I., Hope, J.M., Ivantsov, A., Nettersheim, B.J., Hallmann, C., and Brocks, J.J., 2018, Ancient steroids establish the Ediacaran fossil Dickinsonia as one of the earliest animals: Science, v. 361(6408), p. 1246-1249, doi: 10.1126/science.aat7228.

Bowyer, F., Wood, R.A. and Poulton, S.W., 2017, Controls on the evolution of Ediacaran metazoan ecosystems: a redox perspective: Geobiology, v. 15(4), p. 516-551, doi: $10.1111 /$ gbi.12232.

Brennan, D.T., Mitchell, R.N., Spencer, C.J., Murphy, J.B. and Li, Z.X., 2021, A tectonic model for the Transcontinental Arch: Progressive migration of a Laurentian drainage divide during the Neoproterozoic-Cambrian Sauk Transgression: Terra Nova, p. 1-11, doi: $10.1111 /$ ter.12528.

Brennan, D.T., Pearson, D.M., Link, P.K. and Chamberlain, K.R., 2020, Neoproterozoic Windermere Supergroup near Bayhorse, Idaho: Late-stage Rodinian rifting was deflected west around the Belt basin: Tectonics, v. 39(8), p.e2020TC006145, doi: 10.1029/2020TC006145.

Briggs, D.E.G., 2015, The Cambrian Explosion: Current Biology, v. 25(19), p, R864-R868, doi: 10.1016/j.cub.2015.04.047

Burgess, P. M., 2008, Phanerozoic evolution of the sedimentary cover of the North American craton in Miall, A. D., ed., The Sedimentary Basins of the United States and Canada: Sedimentary Basins of the World, Elsevier, Amsterdam, vol. 5, p. 31-63, doi: 10.1016/S18745997(08)00002-6.

Burgess, P.M., and Gurnis, M., 1995, Mechanisms for the formation of cratonic stratigraphic sequences: Earth and Planetary Science Letters, v. 136(3-4), p. 647-663. doi: 10.1016/0012-821x(95)00204-p.

Burgess, P.M., Gurnis, M., and Moresi, L., 1997, Formation of sequences in the cratonic interior of North America by interaction between mantle, eustatic, and 
stratigraphic processes: Geological Society of America Bulletin, v. 109(12), p.1515-1535, doi: 10.1130/00167606(1997)109

Burns, S.J., and Matter, A., 1993, Carbon isotopic record of the latest Proterozoic from Oman: Eclogae Geologicae Helvetiae, v. 86, p. 595-607.

Canfield, D.E., Knoll, A.H., Poulton, S.W., Narbonne, G.M., and Dunning, G.R., 2020, Carbon isotopes in clastic rocks and the Neoproterozoic carbon cycle: American Journal of Science, v. 320(2), p. 97-124, doi: 10.2475/02.2020.01.

Canfield, D.E., Poulton, S.W., and Narbonne, G.M., 2007, Late-Neoproterozoic deep-ocean oxygenation and the rise of animal life: Science, v. 315(5808), p. 92-95, doi: $10.1126 /$ science.1135013.

Catuneanu, O., Galloway, W.E., Kendall, C.G.S.C., Miall, A.D., Posamentier, H.W., Strasser, A. and Tucker, M.E., 2011, Sequence stratigraphy: methodology and nomenclature: Newsletters on Stratigraphy, v. 44(3), p. 173-245, doi: 10.1127/0078-0421/2011/0011.

Cawood, P.A., Hawkesworth, C.J., and Dhuime, B., 2013, The continental record and the generation of continental crust: Geological Society of America Bulletin, v. 125(1-2), p.14-32, doi: 10.1130/B30722.1.

Cawood, P.A., McCausland, P.J. and Dunning, G.R., 2001, Opening Iapetus: constraints from the Laurentian margin in Newfoundland: Geological Society of America Bulletin, v. 113(4), p. 443-453, doi: 10.1130/00167606(2001)113¡0443:OICFTL¿2.0.CO;2.

Cawood, P.A. and Pisarevsky, S.A., 2017, LaurentiaBaltica-Amazonia relations during Rodinia assembly: Precambrian Research, v. 292, p. 386-397, doi: 10.1016/j.precamres.2017.01.031.

Cecile, M.P., Morrow, D.W., and Williams, G.K., 1997, Early Paleozoic (Cambrian to Early Devonian) tectonic framework, Canadian Cordillera: Bulletin of Canadian Petroleum Geology, v. 34(1), p. 54-74, doi: 10.35767/gscpgbull.45.1.054.

Chen, X., Liu, Y., Kuang, H., Wang, Y., Yang, Z., Vandyk, T.M., Geng, Y., Wang, S., Bai, H., Peng, N., and Xia, X., 2020, Subglacial bedforms and landscapes formed by ice sheet of the Ediacaran-Cambrian age in west Henan, North China: Precambrian Research, v. 344, 105727, doi: 10.1016/j.precamres.2020.105727.
Christie-Blick, N. and Driscoll, N.W., 1995, Sequence stratigraphy: Annual Review of Earth and Planetary Sciences, v. 23(1), p. 451-478, doi: 10.1146/annurev.ea.23.050195.002315.

Christie-Blick, N., Dyson, I.A. and Von Der Borch, C.C., 1995, Sequence stratigraphy and the interpretation of Neoproterozoic Earth history: Precambrian Research, v. 73(1-4), p. 3-26, doi: 10.1016/0301-9268(94)00096-A.

Christie-Blick, N., and Levy, M., 1989, Stratigraphic tectonic framework of upper Proterozoic and Cambrian rocks in the western United States, in Christie-Blick, N., and Levy, M., eds., Late Proterozoic and Cambrian tectonics, sedimentation and record of metazoan radiation in the western United States (International Geological Congress Field-trip Guidebook T331): Washington, D.C., American Geophysical Union, p. 7-21, doi: 10.1029/FT331p0007.

Chumakov, N.M., 2009. The Baykonurian glaciohorizon of the late Vendian: Stratigraphy and Geological Correlation, v. 17(4), p. 373-381, doi: 10.1134/S0869593809040029.

Cloetingh, S.A.P.L., Wortel, M.J.R. and Vlaar, N.J., 1984, Passive margin evolution, initiation of subduction and the Wilson cycle: Tectonophysics, v. 109(1-2), p. 147-163, doi: 10.1016/0040-1951(84)90175-6.

Cochrane, D.J., Navarro, L., and Arnott, R.W.C., 2019, Sedimentological and geochemical evolution of an Ediacaran mixed carbonate-siliciclastic continental slope system, Windermere Supergroup, southern Canadian Cordillera, British Columbia, Canada: Precambrian Research, v. 327, p. 47-67, doi: 10.1016/j.precamres.2019.02.021.

Cohen, K.M., Finney, S.C., Gibbard, P.L., and Fan, J.X., 2013, Updated. The ICS International Chronostratigraphic Chart. Episodes v. 36: p. 199-204.

Cohen, P.A. and Macdonald, F.A., 2015, The Proterozoic record of eukaryotes: Paleobiology, v. 41(4), p. 610-632, doi: $10.1017 /$ pab.2015.25.

Colpron, M., Logan, J.M., and Mortensen, J.K., 2002, $\mathrm{U}-\mathrm{Pb}$ zircon age constraint for late Neoproterozoic rifting and initiation of the lower Paleozoic passive margin of western Laurentia: Canadian Journal of Earth Sciences, v. 39(2), p.133-143, doi: 10.1139/e01-069.

Condie, K.C., 1998, Episodic continental growth and supercontinents: A mantle avalanche connection?: Earth 
and Planetary Science Letters, v. 163, p. 97-108, doi:10.1016/S0012-821X(98)00178-2.

Condie, K.C., 2000, Episodic continental growth models: Afterthoughts and extensions: Tectonophysics, v. 322, p. 153-162, doi:10.1016/S0040-1951(00)00061-5.

Condie, K.C., 2004, Supercontinents and superplume events: Distinguishing signals in the geologic record: Physics of the Earth and Planetary Interiors, v. 146, p. 319-332, doi:10.1016/j.pepi.2003.04.002.

Corsetti, F.A., and Hagadorn, J.W., 2000, PrecambrianCambrian transition: Death Valley, United States: Geology, v. 28(4), p. 299-302, doi: 10.1130/00917613(2000)28¡299:PTDVUS ¿2.0.CO;2.

Corsetti, F.A. and Kaufman, A.J., 1994, Chemostratigraphy of Neoproterozoic-Cambrian units, White-Inyo Region, eastern California and western Nevada; implications for global correlation and faunal distribution: Palaios, v. 9(2), p. 211-219, doi: 10.2307/3515107.

Corsetti, F.A., and Kaufman, A.J., 2003, Stratigraphic investigations of carbon isotope anomalies and Neoproterozoic ice ages in Death Valley, California: Geological Society of America Bulletin, v. 115(8), p. 916-932, doi: 10.1130/B25066.1.

Cramer, B.D., and Jarvis, I., 2020. Chapter 11: Carbon Isotope Stratigraphy, in Gradstein, F.M., Ogg, J.G., Schmitz, M.D., and Ogg, G.M., eds., Geologic Time Scale 2020, Elsevier, Cambridge, 1357 p.

Crampton, J.S., Beu, A.G., Cooper, R.A., Jones, C.M., Marshall, B. and Maxwell, P.A., 2003, Estimating the rock volume bias in paleobiodiversity studies: Science, v. 301(5631), p. 358-360, doi: 10.1126/science.1085075.

Creveling, J.R., Finnegan, S., Mitrovica, J.X., and Bergmann, K.D., 2018, Spatial variation in Late Ordovician glacioeustatic sea-level change: Earth and Planetary Science Letters, v. 496, p. 1-9, doi: 10.1016/j.epsl.2018.05.008.

Cui, H., Kaufman, A.J., Xiao, S., Zhou, C., and Liu, X., 2017, Was the Ediacaran Shuram Excursion a globally synchronized early diagenetic event? Insights from methane-derived authigenic carbonates in the uppermost Doushantuo Formation, South China: Chemical Geology, v. 450, p. 59-80, doi: 10.1016/j.chemgeo.2016.12.010.

Cui, H., Kaufman, A.J., Xiao, S., Zhu, M., Zhou, C. and Liu, X.M., 2015, Redox architecture of an Ediacaran ocean margin: Integrated chemostratigraphic $\left(\delta^{13} \mathrm{C}-\delta^{34} \mathrm{~S}-{ }^{87} \mathrm{Sr} /{ }^{86} \mathrm{Sr}-\mathrm{Ce} / \mathrm{Ce}{ }^{*}\right)$ correlation of the Doushantuo Formation, South China: Chemical Geology v. 405, p. 48-62, doi: 10.1016/j.chemgeo.2015.04.009.

Currie, K.L., and McNicoll, V.J., 1999, New data on the age and geographic distribution of Neoproterozoic plutons near Saint John, New Brunswick: Atlantic Geology, v. $35(2)$, p. $157-166$.

Dalrymple, R.W., and Narbonne, G.M., 1996, Continental slope sedimentation in the Sheepbed Formation (Neoproterozoic, Windermere Supergroup), Mackenzie Mountains, N.W.T: Canadian Journal of Earth Sciences, v. 33, p. 848-862, doi: 10.1139/e96-064.

Darroch, S.A., Smith, E.F., Laflamme, M., and Erwin, D.H., 2018, Ediacaran extinction and Cambrian explosion: Trends in Ecology and Evolution, v. 33(9), p. 653-663, doi: $10.1016 /$ j.tree.2018.06.003.

Darroch, S.A., Sperling, E.A., Boag, T.H., Racicot, R.A., Mason, S.J., Morgan, A.S., Tweedt, S., Myrow, P., Johnston, D.T., Erwin, D.H., and Laflamme, M., 2015, Biotic replacement and mass extinction of the Ediacara biota: Proceedings of the Royal Society B: Biological Sciences, v. 282(1814), p. 1-10, doi: 10.1098/rspb.2015.1003.

de Alvarenga, C.J., Figueiredo, M.F., Babinski, M., and Pinho, F.E., 2007, Glacial diamictites of Serra Azul Formation (Ediacaran, Paraguay belt): evidence of the Gaskiers glacial event in Brazil: Journal of South American Earth Sciences, v. 23(2-3), p. 236-241, doi: 10.1016/j.jsames.2006.09.015.

DeCelles, P.G., 2004, Late Jurassic to Eocene evolution of the Cordilleran thrust belt and foreland basin system, western USA: American Journal of Science, v. 304(2), p. 105-168, doi: 10.2475/ajs.304.2.105.

Denyszyn, S.W., Halls, H.C., Davis, D.W., and Evans, D.A.D., 2009, Paleomagnetism and U-Pb geochronology of Franklinian dykes in High Arctic Canada and Greenland: a revised age and paleomagnetic pole constraining block rotations in the Nares Strait region: Canadian Journal of Earth Sciences, v. 46(9), p. 689-705, doi: 10.1139/E09-042.

Dewey, J. and Spall, H., 1975, Pre-Mesozoic plate tectonics: How far back in Earth history can the Wilson Cycle be extended?: Geology, v. 3(8), p. 422-424, doi: 10.1130/0091-7613(1975)3\%3C422:PPTHFB 
Dewing, K., Harrison, J.C., Pratt, B.R., and Mayr, U., 2004, A probable late Neoproterozoic age for the Kennedy Channel and Ella Bay formations, northeastern Ellesmere Island and its implications for passive margin history of the Canadian Arctic: Canadian Journal of Earth Sciences, v. 41(9), p. 1013-1025, doi: 10.1139/e04-044.

Domeier, M., 2016, A plate tectonic scenario for the Iapetus and Rheic oceans: Gondwana Research, v. 36, p. 275-295, doi: 10.1016/j.gr.2015.08.003.

Dott, R.H., 1983, Episodic sedimentation; how normal is average? How rare is rare? Does it matter?: Journal of Sedimentary Research, v. 53(1), p. 5-23, doi: 10.1306/212F8148-2B24-11D7-8648000102C1865D.

Dott Jr, R.H., 2014, Laurence L. Sloss and the Sequence Stratigraphy Revolution: GSA Today, v. 24, p. 24-26.

Droser, M.L., and Gehling, J.G., 2015, The advent of animals: the view from the Ediacaran: Proceedings of the National Academy of Sciences, v. 112(16), p. 4865-4870, doi: 10.1073/pnas.1403669112.

Dunn, F.S., Liu, A.G., and Donoghue, P.C., 2018, Ediacaran developmental biology: Biological Reviews, v. 93(2), p. 914-932, doi: 10.1111/brv.12379.

Erwin, D.H., 2015, Early metazoan life: divergence, environment and ecology: Philosophical Transactions of the Royal Society B: Biological Sciences, v. 370(1684), p. 1-7, doi: 10.1098/rstb.2015.0036.

Erwin, D.H., Laflamme, M., Tweedt, S.M., Sperling, E.A., Pisani, D., and Peterson, K.J., 2011, The Cambrian conundrum: early divergence and later ecological success in the early history of animals: Science, v. 334(6059), p. 1091-1097, doi: 10.1126/science.1206375.

Etemad-Saeed, N., Hosseini-Barzi, M., Adabi, M.H., Miller, N.R., Sadeghi, A., Houshmandzadeh, A., and Stockli, D.F., 2016, Evidence for ca. 560 Ma Ediacaran glaciation in the Kahar formation, central Alborz Mountains, northern Iran: Gondwana Research, v. 31, p. 164-183, doi: 10.1016/j.gr.2015.01.005.

Eyster, A., Ferri, F., Schmitz, M.D. and Macdonald, F.A., 2018, One diamictite and two rifts: Stratigraphy and geochronology of the Gataga Mountain of northern British Columbia: American Journal of Science, v. 318(2), p. 167-207, doi: 10.2475/02.2018.1.

Faehnrich, K., McClelland, W., Kośmińska, K., and Strauss, J.V., 2019, Geochemistry and tectonic setting of the Yelverton Formation, Ellesmere Island, Canada: A record of Ediacaran-Cambrian extension along the northern margin of Laurentia: American Geophysical Union, Fall Meeting 2019, Abstract \#T13G-0264.

Flowers, R.M., Macdonald, F.A., Siddoway, C.S. and Havranek, R., 2020, Diachronous development of Great Unconformities before Neoproterozoic Snowball Earth: Proceedings of the National Academy of Sciences, v. 117(19), p. 10172-10180, doi: 10.1073/pnas.1913131117.

Ford, T.D., 1958. Pre-Cambrian fossils from Charnwood Forest: Proceedings of the Yorkshire Geological Society, v. 31, p. 211-217, doi: 10.1144/pygs.31.3.211.

Franke, W., Cocks, L.R.M., and Torsvik, T.H., 2017, The Palaeozoic Variscan oceans revisited: Gondwana Research, v. 48, p. 257-284, doi: 10.1016/j.gr.2017.03.005. /j.precamres.2016.01.004.

Gehling, J.G. and Droser, M.L., 2013, How well do fossil assemblages of the Ediacara Biota tell time?: Geology, v. 41(4), p. 447-450, doi: 10.1130/G33881.1.

Gehling, J.G., García-Bellido, D.C., Droser, M.L., Tarhan, M.L. and Runnegar, B., 2019, The EdiacaranCambrian transition: sedimentary facies versus extinction: Estudios Geológicos, v. 75(2), p. 1-6, doi: 10.3989/egeol.43601.554.

Gehling, J.G., Narbonne, G.M., and Anderson, M.M., 2000, The first named Ediacaran body fossil: Aspidella terranovica: Palaeontology, v. 43, p. 427-456, doi:10.1111/j.0031-0239.2000.00134.x.

Gibson, T.M., Faehnrich, K., Busch, J.F., McClelland, W.C., Schmitz, M.D., and Strauss, J.V., 2021, A detrital zircon test of large-scale terrane displacement along the Arctic margin of North America: Geology, v. 49(5), p. 545-550, doi: 10.1130/G48336.1.

Glaessner, M.F., 1959, Precambrian Coelenterata from Australia, Africa and England: Nature, v. 183, p. 14721473, doi: $10.1038 / 1831472 b 0$.

Grotzinger, J.P., Fike, D.A., and Fischer, C.C., 2011, Enigmatic origin of the largest-known carbon isotope excursion in Earth's history: Nature Geoscience, v. 4, p. 285-292, doi: 10.1038/ngeo1138.

Groves, D.I., Vielreicher, R.M., Goldfarb, R.J., and Condie, K.C., 2005, Secular changes in global tectonic processes and their influence on the temporal distribution 
of gold-bearing mineral deposits: Economic Geology and the Bulletin of the Society of Economic Geologists, v. 100, p. 203-224, doi:10.2113/gsecongeo.100.2.203.

Gurnis, M., 1992, Rapid continental subsidence following the initiation and evolution of subduction: Science, v. 255(5051), p. 1556-1558, doi: $10.1126 /$ science.255.5051.1556.

Gurnis, M., 1993, Phanerozoic marine inundation of continents driven by dynamic topography above subducting slabs: Nature, v. 364(6438), p. 589-593, doi: $10.1038 / 364589 \mathrm{a} 0$.

Halverson, G.P., Hoffman, P.F., Schrag, D.P., Maloof, A.C. and Rice, A.H.N., 2005, Toward a Neoproterozoic composite carbon-isotope record: Geological Society of America Bulletin, v. 117(9-10), p.1181-1207, doi: 10.1130/B25630.1.

Halverson, G.P., and Shields-Zhou, G., 2011, Chemostratigraphy and the Neoproterozoic glaciations, in Arnaud, E., Halverson, G.P., and Shields-Zhou, G., eds., The Geological Record of Neoproterozoic Glaciations: Geological Society of London, Memoirs, v. 36, p. 51-66, doi: 10.1144/M36.4.

Haq, B.U., Hardenbol, J.A.N., and Vail, P.R., 1987, Chronology of fluctuating sea levels since the Triassic: Science, v. 235(4793), p.1156-1167, doi: 10.1126/science.235.4793.1156

Haq, B.U. and Schutter, S.R., 2008, A chronology of Paleozoic sea-level changes: Science, v. 322(5898), p. 64-68, doi: 10.1126/science.1161648.

Harrison, J.C, 1995, Melville Island's Salt-Based Fold Belt, Arctic Canada: Ottawa, Natural Resources Canada, Geological Survey of Canada, Bulletin, v. 472, 331 p.

Hatcher, R.D., Jr., 2010, The Appalachian orogen: A brief summary, in Tollo, R.P., Bartholomew, M.J., Hibbard, J.P., and Karabinos, P.M, eds., From Rodinia to Pangea: The Lithotectonic Record of the Appalachian Region: Boulder, Colorado, Geological Society of America, Memoirs, v. 206, p. 1-19, doi: 10.1130/2010.1206(01).

Hatcher, R.D., Jr., Bream, B.R., and Messchat, A.J., 2007, Tectonic map of the southern and central Appalachians: A tale of three orogens and a complete Wilson cycle, in Hatcher, R.D., Jr., Carlson, M.P., McBride, J.H., and Martínez Catalán, J.R., eds., 4-D Framework of Continental Crust: Boulder, Colorado, Geological Society of America Memoirs, v. 200, p. 595-632.
Hawkesworth, C. and Kemp, A.I.S., 2006, Evolution of continental crust: Nature, v. 443, p. 811-817, doi:10.1038/nature05191.

Hebert, C.L., Kaufman, A.J., Penniston-Dorland, S.C., and Martin, A.J., 2010, Radiometric and stratigraphic constraints on terminal Ediacaran (post-Gaskiers) glaciation and metazoan evolution: Precambrian Research, v. 182(4), p. 402-412, doi: 10.1016/j.precamres.2010.07.008.

Hibbard, J.P., van Staal, C.R., and Miller, B.V., 2007, Links among Carolinia, Avalonia, and Ganderia in the Appalachian peri-Gondwanan realm: Geological Society of America Special Papers, v. 433, p. 291-311, doi: 10.1130/2007.2433(14).

Hibbard, J.P., van Staal, C.R., and Rankin, D.W. 2010, Comparative analysis of the geological evolution of the northern and southern Appalachian orogen: Late Ordovician-Permian: Geological Society of America Memoirs, v. 206, p. 51-69, doi: 10.1130/2010.1206(03).

Hodgin, E.B., Nelson, L.L., Wall, C.J., Barrón-Díaz, A.J., Webb, L.C., Schmitz, M.D., Fike, D.A., Hagadorn, J.W. and Smith, E.F., 2021, A link between rift-related volcanism and end-Ediacaran extinction? Integrated chemostratigraphy, biostratigraphy, and U-Pb geochronology from Sonora, Mexico: Geology, v. 49(2), p. 115-119, doi: $10.1130 / \mathrm{G} 47972.1$.

Hoffman, P.F., Halverson, G.P., Domack, E.W., Maloof, A.C., Swanson-Hysell, N.L., and Cox, G.M., 2012, Cryogenian glaciations on the southern tropical paleomargin of Laurentia (NE Svalbard and East Greenland), and a primary origin for the upper Russøya (Islay) carbon isotope excursion: Precambrian Research, v. 206, p. 137-158, doi: 10.1016/j.precamres.2012.02.018.

Hoffman, P.F., Kaufman, A.J., Halverson, G.P. and Schrag, D.P., 1998, A Neoproterozoic snowball earth: Science, v. 281(5381), p. 1342-1346, doi: 10.1126/science.281.5381.1342.

Holland, S. M., 2017, Structure, not Bias: Journal of Paleontology, v. 91(6), p. 1315-1317, doi: 10.1017/jpa.2017.114.

Hurtgen, M.T., Arthur, M.A. and Prave, A.R., 2004, The sulfur isotope composition of carbonate-associated sulfate in Mesoproterozoic to Neoproterozoic carbonates from Death Valley, California: Special Paper of the Geological Society of America, v. 379, p. 177-194, doi: 10.1130/08137-2379-5.177. 
Husson, J.M., Linzmeier, B.J., Kitajiima, K., Ishida, A., Maloof, A.C., Schoene, B., Peters, S.E., and Valley, J.W., 2020, Large isotopic variability at the micron-scale in 'Shuram' excursion carbonates from South Australia: Earth and Planetary Science Letters, v. 538, p. 1-13, doi: 10.1016/j.epsl.2020.116211.

Husson, J.M., and Peters, S.E., 2017, Atmospheric oxygenation driven by unsteady growth of the continental sedimentary reservoir: Earth and Planetary Science Letters, v. 460, p. 68-75, doi: 10.1016/j.epsl.2016.12.012.

Husson, J.M. and Peters, S.E., 2018, Nature of the sedimentary rock record and its implications for Earth system evolution: Emerging Topics in Life Sciences, v. 2(2), p. 125-136, doi: 10.1042/ETLS20170152.

James, N.P., Narbonne, G.M. and Kyser, T.K., 2001, Late Neoproterozoic cap carbonates: Mackenzie Mountains, northwestern Canada: precipitation and global glacial meltdown. Canadian Journal of Earth Sciences: v. 38(8), p. 1229-1262, doi: 10.1139/e01-046.

Jiang, G., Shi, X., Zhang, S., Wang, Y. and Xiao, S., 2011, Stratigraphy and paleogeography of the Ediacaran Doushantuo Formation (ca. 635-551 Ma) in south China: Gondwana Research, v. 19(4), p. 831-849, doi: 10.1016/j.gr.2011.01.006.

Johnston, D.T., Macdonald, F.A., Gill, B.C., Hoffman, P.F. and Schrag, D.P., 2012, Uncovering the Neoproterozoic carbon cycle: Nature, v. 483(7389), p. 320-323, doi: $10.1038 /$ nature10854.

Keller, C.B., Husson, J.M., Mitchell, R.N., Bottke, W.F., Gernon, T.M., Boehnke, P., Bell, E.A., Swanson-Hysell, N.L., and Peters, S.E., 2019, Neoproterozoic glacial origin of the Great Unconformity: Proceedings of the National Academy of Sciences, v. 116(4), p. 1136-1145, doi: $10.1073 /$ pnas. 1804350116 .

Kennedy, M.J., and Christie-Blick, N., 2011, Condensation origin for Neoproterozoic cap carbonates during deglaciation: Geology, v. 39(4), p. 319-322, doi: doi.org/10.1130/G31348.1.

Kennedy, M. J., Christie-Blick, N., and Sohl, L.E., 2001, Are Proterozoic cap carbonates and isotopic excursions a record of gas hydrate destabilization following Earth's coldest intervals?: Geology v. 29(5), p. 443-446, doi: 10.1130/0091-7613(2001)029j0443:APCCAI ¿2.0.CO;2.
Kent, D.V., and Muttoni, G., 2020, Pangea B and the Late Paleozoic Ice Age: Palaeogeography, Palaeoclimatology, Palaeoecology, v. 553, 109753, doi: 10.1016/j.palaeo.2020.109753.

King, A.F., 1980, The birth of the Caledonides: Late Precambrian rocks of the Avalon Peninsula, Newfoundland, and their correlatives in the Appalachian orogen, in Wones, D.R., ed., Proceedings: The Caledonides in the USA: Virginia Polytechnic Institute and State University Memoir 2, p. 3-8.

Knoll, A.H., and Carroll, S.B., 1999, Early animal evolution: emerging views from comparative biology and geology: Science, v. 284(5423), p. 2129-2137, doi: 10.1126/science.284.5423.2129.

Knoll, A.H., Walter, M.R., Narbonne, G.M., and ChristieBlick, N., 2006. The Ediacaran Period: a new addition to the geologic time scale: Lethaia, v. 39, p. 13-30, doi: 10.1080/00241160500409223.

Krogh, T.E., Strong, D.F., O'Brien, S.J., and Papezik, V.S., 1988, Precise U-Pb zircon dates from the Avalon Terrane in Newfoundland: Canadian Journal of Earth Sciences, v. 25, p. 442-453, doi: 10.1139/e88-045.

Laakso, T.A. and Schrag, D.P., 2020, The role of authigenic carbonate in Neoproterozoic carbon isotope excursions: Earth and Planetary Science Letters, v. 549, p. 1-10, doi: 10.1016/j.epsl.2020.116534

Laflamme, M., Darroch, S.A., Tweedt, S.M., Peterson, K.J., and Erwin, D.H., 2013, The end of the Ediacara biota: Extinction, biotic replacement, or Cheshire Cat?: Gondwana Research, v. 23(2), p. 558-573, doi: 10.1016/j.gr.2012.11.004.

Landing, E., 1994. Precambrian-Cambrian boundary global stratotype ratified and a new perspective of Cambrian time. Geology, v. 22(2), p. 179-182, doi: 10.1130/0091-7613(1994)022j0179:PCBGSR ¿2.3.CO;2.

Landing, E., 1996, Avalon: insular continent by the latest Precambrian, in Nance, R.D. and Thompson, M.D., eds., Avalonian and Related Peri-Gondwanan Terranes of the Circum-North Atlantic: Boulder, Colorado, Geological Society of America, Special Papers, v. 304, p. 29-63, doi: 10.1130/SPE304.

Le Guerroué, E., Allen, P. A., and Cozzi, A., 2006, Parasequence development in the Ediacaran Shuram Formation (Nafun Group, Oman): high-resolution strati- 
graphic test for primary origin of negative carbon isotopic ratios: Basin Research, v. 18(2), p. 205-219. doi: 10.1111/j.1365-2117.2006.00292.x.

Lee, C.T.A., Yeung, L.Y., McKenzie, N.R., Yokoyama, Y., Ozaki, K., and Lenardic, A., 2016, Two-step rise of atmospheric oxygen linked to the growth of continents: Nature Geoscience, v. 9(6), p. 417-424, doi: 10.1038/ngeo2707.

Letsch, D., Large, S.J., Buechi, M.W., Winkler, W., and von Quadt, A., 2018, Ediacaran glaciations of the west African Craton-Evidence from Morocco: Precambrian Research, v. 310, p. 17-38, doi: 10.1016/j.precamres.2018.02.015.

Li, C., Love, G.D., Lyons, T.W., Fike, D.A., Sessions, A.L. and Chu, X., 2010, A stratified redox model for the Ediacaran ocean: Science, v. 328(5974), p. 80-83, doi: 10.1126/science.1182369.

Li, C., Shi, W., Cheng, M., Jin, C. and Algeo, T.J., 2020, The redox structure of Ediacaran and early Cambrian oceans and its controls: Science Bulletin v. 65, p. 21412149, doi: 10.1016/j.scib.2020.09.023.

Ling, H.F., Chen, X., Li, D.A., Wang, D., ShieldsZhou, G.A., and Zhu, M., 2013, Cerium anomaly variations in Ediacaran-earliest Cambrian carbonates from the Yangtze Gorges area, South China: implications for oxygenation of coeval shallow seawater: Precambrian Research, v. 225, p. 110-127, doi: 10.1016/j.precamres.2011.10.011.

Linnemann, U., Ovtcharova, M., Schaltegger, U., Gärtner, A., Hautmann, M., Geyer, G., Vickers-Rich, P., Rich, T., Plessen, B., Hofmann, M., and Zieger, J., 2019, New high-resolution age data from the Ediacaran-Cambrian boundary indicate rapid, ecologically driven onset of the Cambrian explosion: Terra Nova, v. 31(1), p. 49-58, doi: 10.1111/ter.12368.

Linnemann, U., Pidal, A.P., Hofmann, M., Drost, K., Quesada, C., Gerdes, A., Marko, L., Gärtner, A., Zieger, J., Ulrich, J., and Krause, R., 2018, A 565 Ma old glaciation in the Ediacaran of peri-Gondwanan West Africa: International Journal of Earth Sciences, v. 107(3), p. 885-911, doi: 10.1007/s00531-017-1520-7.

Liu, A.G., Kenchington, C.G., and Mitchell, E.G., 2015, Remarkable insights into the paleoecology of the Avalonian Ediacaran macrobiota: Gondwana Research, v. 27(4), p. 1355-1380, doi: 10.1016/j.gr.2014.11.002.
Liu, L., Gurnis, M., Seton, M., Saleeby, J., Müller, R.D., and Jackson, J.M., 2010, The role of oceanic plateau subduction in the Laramide orogeny: Nature Geoscience, v. 3(5), p. 353-357, doi: 10.1038/ngeo829.

Loyd, S.J., Marenco, P.J., Hagadorn, J.W., Lyons, T.W., Kaufman, A.J., Sour-Tovar, F., and Corsetti, F.A., 2012, Sustained low marine sulfate concentrations from the Neoproterozoic to the Cambrian: Insights from carbonates of northwestern Mexico and eastern California: Earth and Planetary Science Letters, v. 339-340, p. 79-94, doi: 10.1016/j.epsl.2012.05.032.

Lund, K., 2008, Geometry of the Neoproterozoic and Paleozoic rift margin of western Laurentia: Implications for mineral deposit settings: Geosphere, v. 4(2), p. 429444, doi: 10.1130/GES00121.1.

Macdonald, F.A. and Cohen, P.A., 2011, The Tatonduk inlier, Alaska-Yukon border. Geological Society of London Memoirs: v. 36(1), p. 389-396, doi: 10.1144/M36.35.

Macdonald, F.A., Halverson, G.P., Strauss, J.V., Smith, E.F., Cox, G., Sperling, EA. and Roots, C.F., 2012, Early Neoproterozoic Basin Formation in Yukon, Canada: Implications for the make-up and break-up of Rodinia: Geoscience Canada, v. 39(2), p. 77-100, URI: https://id.erudit.org/iderudit/geocan39_2pfh01

Macdonald, F.A., McClelland, W.C., Schrag, D.P. and Macdonald, W.P., 2009, Neoproterozoic glaciation on a carbonate platform margin in Arctic Alaska and the origin of the North Slope subterrane. Geological Society of America Bulletin: v. 121(3-4), p. 448-473, doi: 10.1130/B26401.1.

Macdonald, F.A., Straus, J.V., Sperling, E.A., Halverson, G.P., Narbonne, G.M., Johnston, D.T., Kunzmann, M., Schrag, D.P., and Higgins, J.A., 2013, The stratigraphic relationship between the Shuram carbon isotope excursion, the oxygenation of Neoproterozoic oceans, and the first appearance of the Ediacara biota in bilaterian trace fossils in northwestern Canada: Chemical Geology, v. 362, p. 250-272, doi: 10.1016/j.chemgeo.2013.05.032.

Mancuso, C.I., Gates, A.E., and Puffer, J.H., 1996, Geochemical and petrologic evidence of Avalonian arc to rift transition from granitoids in southeastern Rhode Island, in Nance, R.D., Thompson, M.D., eds., Avalonian and Related Peri-Gondwanan Terranes of the CircumNorth Atlantic. Boulder, Colorado, Geological Society of America, Special Papers, v. 304, p. 29-63, doi: 10.1130/08137-2304-3.193. 
Marshall, C.R., 2006, Explaining the Cambrian "explosion" of animals: Annual Review of Earth and Planetary Sciences, v. 34, p. 355-384, doi: 10.1146/annurev.earth.33.031504.103001.

McGee, B., Collins, A.S., and Trindade, R.I., 2013, A glacially incised canyon in Brazil: Further evidence for mid-Ediacaran glaciation?: The Journal of Geology, v. 121(3), p. 275-287, doi: 10.1086/669979.

McMenamin, M.A., 1996, Ediacaran biota from Sonora, Mexico: Proceedings of the National Academy of Sciences, v. 93(10), p. 4990-4993, doi: 10.1073/pnas.93.10.4990.

Menon, L.R., McIlroy, D., Brasier, M.D., 2013, Evidence for Cnidaria-like behavior in ca. 560 Ma Ediacaran Aspidella: Geology, v. 41(8), p. 895-898, doi: 10.1130/G34424.1.

Merdith, A.S., Williams, S.E., Brune, S., Collins, A.S., and Müller, R.D., 2019, Rift and plate boundary evolution across two supercontinent cycles: Global and Planetary Change, v. 173, p. 1-14, doi: 10.1016/j.gloplacha.2018.11.006.

Meyers, S.R. and Peters, S.E., 2011, A 56 million year rhythm in North American sedimentation during the Phanerozoic: Earth and Planetary Science Letters, v. 303(3-4), p. 174-180, doi: 10.1016/j.epsl.2010.12.044.

Miall, A.D., 2016, The valuation of unconformities: Earth-Science Reviews, v. 163, p. 22-71, doi: 10.1016/j.earscirev.2016.09.011.

Miller, K.G., Kominz, M.A., Browning, J.V., Wright, J.D., Mountain, G.S., Katz, M.E., Sugarman, P.J., Cramer, B.S., Christie-Blick, N., and Pekar, S.F., 2005, The Phanerozoic record of global sea-level change: Science, v. 310(5752), p. 1293-1298, doi: 10.1126/science. 1116412 .

Mills, D.B., Ward, L.M., Jones, C., Sweeten, B., Forth, M., Treusch, A.H., and Canfield, D.E., 2014, Oxygen requirements of the earliest animals: Proceedings of the National Academy of Sciences, v. 111(11), p. 4168-4172, doi: $10.1073 /$ pnas.1400547111.

Montañez, I.P. and Poulsen, C.J., 2013, The Late Paleozoic ice age: an evolving paradigm: Annual Review of Earth and Planetary Sciences, v. 41, p.629-656, doi: 10.1146/annurev.earth.031208.100118.

Moynihan, D.P., Strauss, J.V., Nelson, L.L., and Padget, C.D., 2019, Upper Windermere Supergroup and the transition from rifting to continent-margin sedimentation, Nadaleen River area, northern Canadian Cordillera: Geological Society of America Bulletin, v. 131(9-10), p. 1673-1701, doi: 10.1130/B32039.1.

Murphy, J.B., Pisarevsky, S.A., Nance, R.D., and Keppie, J.D., 2004, Neoproterozoic-early Paleozoic configuration of peri-Gondwanan terranes: Implications for LaurentiaGondwanan connections: International Journal of Earth Sciences, v. 93, p. 659-682, doi: 10.1007/s00531-0040412-9.

Murphy, J.B., Keppie, J.D., Davis, D., and Krogh, T.E., 1997, Regional significance of new $\mathrm{U}-\mathrm{Pb}$ age data for Neoproterozoic igneous units in Avalonian rocks of northern mainland Nova Scotia, Canada: Geological Magazine, v. 134(1), p. 113-120, doi: 10.1017/S0016756897006596.

Murphy, J.B., Nance, R.D., Keppie, J.D., and Dostal, J., 2019, Role of Avalonia in the development of tectonic paradigms in Wilson, R.W., Houseman, G.A., McCaffrey, K.J.W., Doré, A.G., and Buiter, S.J.H., eds., Fifty Years of the Wilson Cycle Concept in Plate Tectonics: London, Geological Society of London, Special Publications, v. 470(1), p. 265-287, doi: 10.1144/SP470.12.

Murray, A., 1869, The economic value of a geological survey: Geological Survey of Canada, printed by John Lovell, Montreal, 20 p.

Myrow, P.M. and Kaufman, A.J., 1999, A newly discovered cap carbonate above Varanger-age glacial deposits in Newfoundland: Canadian Journal of Sedimentary Research, v. 69(3), p. 784-793, doi: 10.2110/jsr.69.784.

Nance, R.D., Murphy, J.B., and Santosh, M., 2014, The supercontinent cycle: a retrospective essay: Gondwana Research, v. 25(1), p. 4-29, doi: 10.1016/j.gr.2012.12.026.

Nance, R.D., Murphy, J.B., Strachan, R.A., Keppie, J.D., Gutiérrez-Alonso, G., Fernández-Suárez, J., Quesada, C., Linnemann, U., D'Lemos, R., and Pisarevsky, S.A., 2008, Neoproterozoic-early Paleozoic tectonostratigraphy and palaeogeography of the peri-Gondwanan terranes: Amazonian v. West African connection in Ennih, N., Liégeois, J-P. eds., The boundaries of the West African Craton: Geological Society of London Special Publication, v. 297, p. 345-383, doi: 10.1144/SP297.17.

Nance, R.D., Worsley, T.R., and Moody, J.B., 1988, The supercontinent cycle: Scientific American, v. 256, p. 72-79, doi: 10.1038/scientificamerican0788-72. 
Narbonne, G.M., Kaufman, A.J. and Knoll, A.H., 1994, Integrated chemostratigraphy and biostratigraphy of the Windermere Supergroup, northwestern Canada: Implications for Neoproterozoic correlations and the early evolution of animals: Geological Society of America Bulletin, v. 106(10), p. 1281-1292, doi: 10.1130/00167606(1994)106;1281:ICABOT¿2.3.CO;2.

Narbonne, G.M., and Gehling, J.G., 2003, Life after Snowball: The oldest complex Ediacaran fossils: Geology, v. 31(1), p. 27-30, doi: 10.1130/00917613(2003)031;0027:LASTOC ¿2.0.CO;2.

Narbonne, G.M., Xiao, S., and Shields, G., 2012, Chapter 18: Ediacaran Period in Gradstein, F., Ogg, J., and Ogg, G., eds., Geologic Timescale 2012: Cambridge, Elsevier, p. $427-449$.

Nawrot, R., Scarponi, D., Azzarone, M., Dexter, T.A., Kusnerik, K.M., Wittmer, J.M., Amorosi, A. and Kowalewski, M., 2018, Stratigraphic signatures of mass extinctions: ecological and sedimentary determinants: Proceedings of the Royal Society B: Biological Sciences, v. 285(1886), doi: 10.1098/rspb.2018.1191.

Newell, N.D., 1959, The nature of the fossil record: Proceedings of the American Philosophical Society, v. 103(2), p. 264-285.

O'Brien, S. J., O'Brien, B. H., Dunning, G. R., and Tucker, R. D., 1996, Late Neoproterozoic Avalonian and related peri-Gondwanan rocks of the Newfoundland Appalachians in Nance, R.D., and Thompson, M.D., eds., Avalonian and Related Peri-Gondwanan Terranes of the Circum-North Atlantic: Boulder, Colorado, Geological Society of America, Special Papers, v. 304, p. 9-28.

Partin, C.A., Bekker, A., Planavsky, N.J., Scott, C.T., Gill, B.C., Li, C., Podkovyrov, V., Maslov, A., Konhauser, K.O., Lalonde, S.V., and Love, G.D., 2013, Large-scale fluctuations in Precambrian atmospheric and oceanic oxygen levels from the record of $U$ in shales: Earth and Planetary Science Letters, v. 369, p. 284-293, doi: 10.1016/j.epsl.2013.03.031.

Pe-Piper, G., Piper, D.J.W., and Koukouvelas, I., 1996, The Precambrian plutons of the Cobequid Highlands, Nova Scotia in Nance, R.D. and Thompson, M.D., eds., Avalonian and Related Peri-Gondwanan Terranes of the Circum-North Atlantic: Boulder, Colorado, Geological Society of America, Special Papers v. 304, p. 121-132.

Peters, S.E., 2005, Geologic constraints on the macroevolutionary history of marine animals. Proceedings of the
National Academy of Sciences, v. 102(35), p.12326-12331, doi: $10.1073 /$ pnas.0502616102.

Peters, S.E., 2006, Macrostratigraphy of North America: Journal of Geology, v. 114(4), p. 391-412, doi: $10.1086 / 504176$.

Peters, S.E., 2008, Macrostratigraphy and its promise for paleobiology: The Paleontological Society Papers, v. 14, p. 205-231, doi: 10.1017/S1089332600001698.

Peters, S.E. and Gaines, R.R., 2012, Formation of the 'Great Unconformity' as a trigger for the Cambrian explosion: Nature, v. 484(7394), p. 363-366, doi: 10.1038/nature10969.

Peters, S.E. and Heim, N.A., 2011a, Macrostratigraphy and macroevolution in marine environments: testing the common-cause hypothesis: Geological Society of London Special Publications, v. 358(1), p. 95-104, doi: 10.1144/SP358.7.

Peters, S.E. and Heim, N.A., 2011b, Stratigraphic distribution of marine fossils in North America: Geology, v. 39(3), p. 259-262, doi: 10.1130/G31442.1.

Peters, S.E. and Husson, J.M., 2017, Sediment cycling on continental and oceanic crust: Geology, v. 45(4), p. 323-326, doi: 10.1130/G38861.1.

Peters, S.E., Husson, J.M., and Czaplewski, J., 2018, Macrostrat: A platform for geological data integration and deep-time earth crust research: Geochemistry, Geophysics, Geosystems, v. 19, p. 1393-1409, doi: 10.1029/2018GC007467.

Peters, S., Walton, C., Husson, J., Quinn, D., Shorttle, O., Keller, B., and Gaines, R., 2021, Igneous rock area and age in continental crust: Geology, doi: 10.17863/CAM.69303.

Petterson, R., Prave, A.R., Wernicke, B.P. and Fallick, A.E., 2011, The Neoproterozoic Noonday Formation, Death Valley region, California: Geologic Society of America Bulletin, v. 123(7-8), p. 1317-1336, doi: 10.1130/B30281.1.

Pollock, J.C., Hibbard, J.P., and Sylvester, P.J., 2009, Early Ordovician rifting of Avalonia and birth of the Rheic Ocean: U-Pb detrital zircon constraints from Newfoundland: Journal of the Geological Society of London, v. 166(3), p. 501-515, doi: 10.1144/0016-76492008-088. 
Post, R.T., and Long, D.G.F., 2008, The Middle Cambrian Mount Roosevelt Formation (new) of northeastern British Columbia: Evidence for rifting and development of the Kechika Graben System: Canadian Journal of Earth Sciences, v. 45, p. 483-498, doi: 10.1139/E08-014.

Pu, J.P., Bowring, S.A., Ramezani, J., Myrow, P., Raub, T.D., Landing, E., Mills, A., Hodgin, E., and Macdonald, F.A., 2016, Dodging snowballs: Geochronology of the Gaskiers glaciation and the first appearance of the Ediacaran biota: Geology, v. 44(11), p. 955-958, doi: 10.1130/G38284.1.

Rankin , D.W., 1975, The continental margin of eastern

North America in the southern Appalachians: The opening and closing of the proto-Atlantic Ocean: American Journal of Science, v. 275(A), p. 298-336.

Raup, D.M., 1972, Taxonomic diversity during the Phanerozoic: Science, v. 177(4054), p. 1065-1071.

Raup, D.M., 1976, Species diversity in the Phanerozoic: an interpretation: Paleobiology, v. 2(4), p. 289-297.

Ronov, A.B., Khain, V.E., Balukhovsky, A.N., and Seslavinsky, K.B., 1980, Quantitative analysis of Phanerozoic sedimentation: Sedimentary Geology, v. 25(4), p. 311-325, doi: 10.1016/0037-0738(80)90067-6.

Rooney, A.D., Cantine, M.D., Bergmann, K.D., GómezPérez, I., Al Baloushi, B., Boag, T.H., Busch, J.F., Sperling, E.A., and Strauss, J.V., 2020, Calibrating the coevolution of Ediacaran life and environment: Proceedings of the National Academy of Sciences, v. 117(29), p. 16824-16830, doi: 10.1073/pnas.2002918117.

Rooney, A.D., Strauss, J.V., Brandon, A.D., and Macdonald, F.A., 2015, A Cryogenian chronology: Two longlasting synchronous Neoproterozoic glaciations: Geology, v. 43(5), p. 459-462, doi: 10.1130/G36511.1.

Ross, G.M., 1991, Tectonic setting of the Windermere Supergroup revisited: Geology, v. 19, p. 1125-1128, doi: 10.1130/0091-7613(1991)019¡1125:TSOTWS ¿2.3.CO;2.

Ross, G.M., and Arnott, R.W.C. 2007, Regional Geology of the Windermere Supergroup, Southern Canadian Cordillera and Stratigraphic Setting of the Castle Creek Study Area, Canada, in Nilsen, T.H., Shew, R.D., Steffens, G.S., Studlick, J.R.J., eds., Atlas of deep-water outcrops: AAPG Studies in Geology, v. 56, CD-ROM, doi: 10.1306/12401038St563286.
Ross, C.A. and Ross, J.R.P., 1987, Late Paleozoic Sea Levels and Depositional Sequences in Ross, C.A. and Haman, D., eds., Timing and Depositional History of Eustatic Sequences: Constraints on Seismic Stratigraphy: Washington, D.C., Cushman Foundation for Foraminiferal Research, Special Publications, v. 24, p. 137-149.

Sahoo, S.K., Planavsky, N.J., Kendall, B., Wang, X., Shi, X., Scott, C., Anbar, A.D., Lyons, T.W., and Jiang, G., 2012, Ocean oxygenation in the wake of the Marinoan glaciation: Nature, v. 489(7417), p. 546-549, doi: 10.1038/nature11445.

Sarg, J.F., 1988, Carbonate sequence stratigraphy in Wilgus, C.K., Hastings, B.S., Kendall, C.G.St.C., Posamentier, H.W., Ross, C.A., and Van Wagoner, J.C., eds. Sea Level Changes: An Integrated Approach, Society of Economic Paleontologists and Mineralogists Special Publication, v. 42, p. 155-181, doi: 10.2110/pec.88.01.0155.

Schofield, D.I., Potter, J., Barr, S.M., Horák, J.M., Millar, I.L., and Longstaffe, F.J., 2016, Reappraising the Neoproterozoic 'East Avalonian' terranes of southern Great Britain: Gondwana Research, v. 35, p. 257-271, doi: 10.1016/j.gr.2015.06.001.

Schrag, D.P., Higgins, J.A., Macdonald, F.A., and Johnston, D.T., 2013, Authigenic carbonate and the history of the global carbon cycle: Science, v. 339, p. 540-543, doi: $10.1126 /$ science.1229578.

Seilacher, R. W. 1984, Late Precambrian and Early Cambrian metazoa: preservational or real extinctions? in Holland, H.D., and Trendall, A.F., eds., Patterns of change in Earth evolution: Heidelberg, Berlin, Springer, p. $159-168$.

Shahkarami, S., Buatois, L.A., Mángano, M.G., Hagadorn, J.W., and Almond, J., 2020, The Ediacaran-Cambrian boundary: Evaluating stratigraphic completeness: Precambrian Research, v. 345, 105721, doi: $10.1016 /$ j.precamres.2020.105721.

Shields, G.A., Mills, B.J.W., Zhu, M., Raub, T.D., Daines, S.J., and Lenton, T.M., 2019, Unique Neoproterozoic carbon isotope excursions sustained by coupled evaporite dissolution and pyrite burial: Nature Geoscience, v. 12, p. 823-827, doi: 10.1038/s41561-019-0434-3.

Sloss, L.L., 1963, Sequences in the cratonic interior of North America: Geological Society of America Bulletin, v. 74(2), p.93-114, doi: 10.1130/00167606(1963)74[93:SITCIO]2.0.CO;2. 
Sloss, L.L., 1988, Forty years of sequence stratigraphy: Geological Society of America Bulletin, v. 100(11), p. 1661-1665, doi: 10.1130/00167606(1988)100¡1661:FYOSS ¿2.3.CO;2.

Smit, J., van Wees, J.D., and Cloetingh, S., 2018, Early Carboniferous extension in East Avalonia: 350 My record of lithospheric memory: Marine and Petroleum Geology, v. 92, p. 1010-1027, doi: 10.1016/j.marpetgeo.2018.01.004.

Smith, E.F., Macdonald, F.A., Petach, T.A., Bold, U. and Schrag, D.P., 2016a, Integrated stratigraphic, geochemical, and paleontological late Ediacaran to early Cambrian records from southwestern Mongolia: Geological Society of America Bulletin, v. 128(3-4), p. 442-468, doi: 10.1130/B31248.1.

Smith, E.F., Nelson, L.L., Strange, M.A., Eyster, A.E., Rowland, S.M., Schrag, D.P. and Macdonald, F.A., 2016b, The end of the Ediacaran: Two new exceptionally preserved body fossil assemblages from Mount Dunfee, Nevada, USA: Geology, v. 44(11), p. 911-914, doi: 10.1130/G38157.1.

Smith, E.F., Nelson, L.L., Tweedt, S.M., Zeng, H. and Workman, J.B., 2017, A cosmopolitan late Ediacaran biotic assemblage: new fossils from Nevada and Namibia support a global biostratigraphic link: Proceedings of the Royal Society B: Biological Sciences, v. 284(1858), doi: 10.1098/rspb.2017.0934.

Sour-Tovar, F., Hagadorn, J.W., and Huitrón-Rubio, T., 2007, Ediacaran and Cambrian index fossils from Sonora, Mexico: Palaeontology, v. 50(1), p. 169-175, doi: 10.1111/j.1475-4983.2006.00619.x.

Southworth, S., Tollo, R.P., Aleinikoff, J.N., Bailey, C., Burton, W.C., Crider, E., Hackley, P.C., Kunk, M.J., Mundil, R., Naeser, C.N., Naeser, N., and Smoot, J., 2009, New geologic map and geochronology of the Shenandoah National Park region, Virginia: Geological Society of America Abstracts with Programs, v. 41, no. 365.

Sperling, E.A., Carbone, C., Strauss, J.V., Johnston, D.T., Narbonne, G.M. and Macdonald, F.A., 2016, Oxygen, facies, and secular controls on the appearance of Cryogenian and Ediacaran body and trace fossils in the Mackenzie Mountains of northwestern Canada: Geological Society of America Bulletin, v. 128(3-4), p. 558-575, doi: 10.1130/B31329.1.

Sperling, E.A., Frieder, C.A., Raman, A.V., Girguis, P.R., Levin, L.A., and Knoll, A.H., 2013, Oxygen, ecology, and the Cambrian radiation of animals: Proceedings of the National Academy of Sciences, v. 110(33), p. 1344613451, doi: 10.1073/pnas.1312778110.

Sperling, E.A., Knoll, A.H., and Girguis, P.R., 2015a, The ecological physiology of Earth's second oxygen revolution: Annual Review of Ecology, Evolution, and Systematics, v. 46, p. 215-235, doi: 10.1146/annurev-ecolsys-110512135808 .

Sperling, E.A., Wolock, C.J., Morgan, A.S., Gill, B.C., Kunzmann, M., Halverson, G.P., Macdonald, F.A., Knoll, A.H., and Johnston, D.T., 2015b, Statistical analysis of iron geochemical data suggests limited late Proterozoic oxygenation: Nature, v. 523(7561), p. 451-454, doi: 10.1038/nature14589.

Sprigg, R.C., 1947, Early Cambrian (?) jellyfishes from the Flinders Ranges, South Australia: Transactions of the Royal Society of South Australia, v. 71(2), p. 212-224.

Stewart, J.H., 1972, Initial deposits in the cordilleran geosyncline; evidence of a late Precambrian (i 850 m.y.) continental separation: Geological Society of America Bulletin, v. 83, p. 1345-1360, doi: 10.1130/00167606(1972)83[1345:IDITCG]2.0.CO;2.

Strauss, J.V., MacDonald, F.A., Halverson, G.P., Tosca, N.J., Schrag, D.P., and Knoll, A.H., 2015, Stratigraphic evolution of the Neoproterozoic Callison Lake Formation: Linking the break-up of Rodinia to the Islay carbon isotope excursion: American Journal of Science, v. 315(10), p. 881-944, doi: 10.2475/10.2015.01.

Tarhan, L.G., Droser, M.L., Cole, D.B. and Gehling, J.G., 2018, Ecological expansion and extinction in the late Ediacaran: Weighing the evidence for environmental and biotic drivers: Integrative and Comparative Biology, v. 58(4), p. 688-702, doi: 10.1093/icb/icy020.

Thomas, W.A., 1991, The Appalachian-Ouachita rifted margin of southeastern North America: Geological Society of America Bulletin, v. 103, p. 415-431, doi: 10.1130/0016-7606(1991)103¡0415:TAORMO ¿2.3.CO;2.

Vail, P.R., Mitchum, R.M., and Thompson, S.,III, 1977, Seismic stratigraphy and global changes of sea level, Part 3: Relative changes of sea level from coastal onlap in Payton, C. W., ed., Seismic Stratigraphy: Applications to Hydrocarbon Exploration: American Association of Petroleum Geologists Memoir, v. 26, p. 83-97. 
Valentine J.W., 2002, Prelude to the Cambrian explosion: Annual Review of Earth and Planetary Sciences, v. 32, p. 285-306, doi: 10.1146/annurev.earth.30.082901.092917.

van Staal, C.R., Barr, S.M., McCausland, P.J.A., Thompson, M.D., and White, C.E., 2020. Tonian-Ediacaran tectonomagmatic evolution of West Avalonia and its Ediacaran-Early Cambrian interactions with Ganderia: an example of complex terrane transfer due to arc-arc collision?: Geological Society of London Special Publications, v. 503, p. 143-167 doi: 10.1144/SP503-2020-23.

van Staal, C.R., Barr, S.M., and Murphy, J.B., 2012, Provenance and tectonic evolution of Ganderia: Constraints on the evolution of the Iapetus and Rheic oceans: Geology, v. 40(11), p. 987-990, doi: 10.1130/G33302.1.

van Staal, C.R., Whalen, J.B., Valverde-Vaquero, P., Zagorevski, A. and Rogers, N., 2009, Pre-Carboniferous, episodic accretion-related, orogenesis along the Laurentian margin of the northern Appalachians: Geological Society of London Special Publications, v. 327(1), p. 271-316, doi: 10.1144/SP327.13.

Van Wagoner, J.C., Posamentier, H.W., Mitchum, R.M., Vail, P.R., Sarg, J.F., Loutit, T.S., and Hardenbol, J., 1988, An overview of the fundamentals of sequence stratigraphy and key definitions in Wilgus, C. K., Posamenier, H., Ross, C. A., and Kendall, C.G.St.C., eds., Sea-Level Changes: an Integrated Approach: Society of Economic Paleontologists and Mineralogists Special Publication, v. 42, p. 39-45, doi: 10.2110/pec.88.01.0039.

Verdel, C., Wernicke, B.P., and Bowring, S.A., 2011, The Shuram and subsequent Ediacaran carbon isotope excursions from southwest Laurentia, and implications for environmental stability during the metazoan radiation: Geological Society of America Bulletin, v. 123(7-8), p. 1539-1559, doi: 10.1130/B30369.1.

Vernhet, E., Youbi, N., Chellai, E.H., Villeneuve, M., and El Archi, A., 2012, The Bou-Azzer glaciation: evidence for an Ediacaran glaciation on the west African craton (anti-atlas, Morocco): Precambrian Research, v. 196, p. 106-112, doi: 10.1016/j.precamres.2011.11.009.

Waldron, J. W. F., Schofield, D. I., and Murphy, J. B., 2019, Diachronous Palaeozoic accretion of periGondwanan terranes at the Laurentian margin in Wilson, R.W., Houseman, G.A., McCaffrey, K.J.W., Doré, A.G., and Buiter, S.J.H., eds., Fifty Years of the Wilson Cycle Concept in Plate Tectonics: London, Geological Society of London, Special Publications, v. 470(1), p. 289-310, doi: $10.1144 /$ SP470.11.

Walcott, R.I., 1972, Gravity, flexure and the growth of sedimentary basins at a continental edge: Geological Society of America Bulletin, v. 83, p. 1845-1848, doi: 10.1130/0016-7606(1972)83

Wang, D., Ling, H.F., Struck, U., Zhu, X.K., Zhu, M., He, T., Yang, B., Gamper, A., and Shields, G.A., 2018, Coupling of ocean redox and animal evolution during the Ediacaran-Cambrian transition. Nature Communications, v. 9(1), p. 1-8, doi: https://doi.org/10.1038/s41467-018-04980-5.

Weaver, P.G., McMenamin, M.A., and Tacker, R.C., 2006, Paleoenvironmental and paleobiogeographic implications of a new Ediacaran body fossil from the Neoproterozoic Carolina Terrane, Stanly County, North Carolina: Precambrian Research, v. 150(3-4), p. 123-135, doi: 10.1016/j.precamres.2006.07.002.

Williams, J.J., Mills, B.J., and Lenton, T.M., 2019, A tectonically driven Ediacaran oxygenation event: Nature Communications, v. 10(1), p. 1-10, doi: 10.1038/s41467019-10286-x.

Willman, S., Peel, J.S., and Ineson, J.R., 2020, Ediacaran Doushantuo-type biota discovered in Laurentia: Communications Biology, v. 3(1), p. 1-10, doi: 10.1038/s42003020-01381-7.

Wilson, J.T., 1966, Did the Atlantic close and then reopen?: Nature, v. 211, p. 676-681.

Wilson, R.W., Houseman, G.A., Buiter, S.J.H., McCaffrey, K.J.W., and Doré, A.G., 2019, Fifty Years of the Wilson Cycle Concept in Plate Tectonics: London, Geological Society of London, Special Publications, v. 470(1), p. 289-310, doi: 10.1144/SP470-2019-58.

Winchester, J.A., Pharaoh, T.C., and Verniers, J., 2002, Palaeozoic amalgamation of Central Europe: an introduction and synthesis of new results from recent geological and geophysical investigations in Winchester, J.A., Pharaoh, T.C., and Verniers, J., eds., Palaeozoic Amalgamation of Central Europe: London, Geological Society of London, Special Publications, v. 201, p. 1-18, doi: 10.1144/GSL.SP.2002.201.01.01.

Witkosky, R., and Wernicke, B.P., 2018, Subsidence history of the Ediacaran Johnnie Formation and related strata of southwest Laurentia: Implications for the age 
and duration of the Shuram isotopic excursion and animal evolution: Geosphere, v. 14(5), p. 2245-2276, doi: 10.1130/GES01678.1.

Wu, X., Xu, S., Wu, S., Li, S., Wang, D., Xiao, Y., Wang, J., and Somerville, I., 2017, Main sedimentary sequences and stages of major cratonic basins during the breakup of Rodinia: Geological Journal, v. 52, p. 329-338, doi: doi.org/10.1002/gj.3099.

Xiao, S.H., and Laflamme, M., 2009, On the eve of animal radiation: phylogeny, ecology and evolution of the Ediacara biota: Trends in Ecology and Evolution, v. 24(1), p. 31-40, doi: 10.1016/j.tree.2008.07.015.

Xiao, S.H., and Narbonne, G.M., 2020, Chapter 18: The Ediacaran Period in Gradstein, F.M., Ogg, J.G., Schmitz, M.D., and Ogg, G.M., eds., Geologic Time Scale 2020, Elsevier, Cambridge, 1357 p.

Xiao, S., Narbonne, G.M., Zhou, C., Laflamme, M., Grazhdankin, D.V., Moczydłowska-Vidal, M. and Cui, H., 2016, Towards an Ediacaran time scale: problems, protocols, and prospects: Episodes, v. 39(4), p. 540-555, doi: 10.18814/epiiugs/2016/v39i4/103886.

Yang, D., Guo, X., Xie, T., and Luo, X., 2018, Reactive oxygen species may play an essential role in driving biological evolution: the Cambrian Explosion as an example: Journal of Environmental Sciences, v. 63, p. 218-226, doi: 10.1016/j.jes.2017.05.035.

Yang, J., Lyons, T.W., Zeng, Z., Odigie, K.O., Bates, S., and $\mathrm{Hu}$, L., 2019, Geochemical constraints on the origin of Neoproterozoic cap carbonate in the Helan Mountains, North China: Implications for mid-late Ediacaran glaciation?: Precambrian Research, v. 331, 105361, doi: 10.1016/j.precamres.2019.105361.

Yonkee, W., Dehler, C., Link, P., Balgord, E., Keeley, J., Hayes, D., Wells, M., Fanning, C., and Johnston, S., 2014, Tectono-stratigraphic framework of Neoproterozoic to Cambrian strata, west-central U.S.: Protracted rifting, glaciation, and evolution of the North American Cordilleran margin: Earth-Science Reviews, v. 136, p. 59-95, doi: 10.1016/j.earscirev.2014.05.004.

Zaffos, A., Finnegan, S. and Peters, S.E., 2017, Plate tectonic regulation of global marine animal diversity: Proceedings of the National Academy of Sciences, v. 114(22), p. 5653-5658, doi: 10.1073/pnas.1702297114.

Zhang, X. and Cui, L., 2016, Oxygen requirements for the Cambrian explosion: Journal of Earth Science, v. 27(2), p. 187-195, doi: 10.1007/s12583-016-0690-8. 